\title{
RELEVANSI PENDIDIKAN MULTIKULTURALISME NABI MUHAMMAD DALAM KONTEKS KEINDONESIAAN : SPIRIT PROFETIK DALAM MENGELOLA KERAGAMAN DI BASIS MASYARAKAT MULTIKULTURAL
}

\author{
Erna Herawati \\ faridatul_mahya@uin-malang.ac.id \\ Universitas Islam Negeri Maulana Malik Ibrahim Malang \\ Ratih Kusuma Ningtias \\ ratihkusuma@iai-tabah.ac.id \\ Institut Agama Islam Tarbiyatut Tholabah Lamongan \\ M. Rudi Habibie \\ rudi_habibie@yahoo.com \\ Sekolah Menengah Atas Negeri 1 Baureno Bojonegoro
}

\begin{abstract}
This article aims to analyze the pattern of the Prophet Muhammad SAW in managing the heterogeneity of the people of Medina in a tolerant and inclusive manner. At the same time, this article also aims to pitch and contextualize the patrons of the Prophet Muhammad in managing ethnic, cultural, and religious diversity in the context of religious education in Indonesia. On the other hand, this article also aims to find common ground between Pancasila and the values of the Prophet Muhammad's teachings on religious tolerance in the Medina Charter. The analytical method used in this article is a literature study that emphasizes data analysis on various authoritative literature sources. There are several findings in this article, namely: First, the position of the Prophet Muhammad as head of state who was able to initiate the birth of the Medina charter should be seen as the theoretical forerunner of multiculturalism education. To realize this multiculturalism education, the Prophet Muhammad used the theology of rabmatan lil 'alamin as cognitive, affective, and psychomotor fuel. The plural society of Medina was educated by the Prophet Muhammad through the values of universal Islamic teachings. The example of the Prophet Muhammad with his universal character became an important capital for the realization of an attitude of tolerance in responding to the multiculturalism of the people of Medina. Second, Indonesia as a country consisting of various variants of race, ethnicity, religion, and culture is relevant for promoting the values of multiculturalism. Third, at the same time, Pancasila which is used as the philosophy of state life by the Indonesian people is in line with the teachings of tolerance amid the multicultural life of the people of Medina. Religious, ethnic, and cultural diversity can be embroidered and knitted in harmony through universal Islamic values as contained in Pancasila.
\end{abstract}

Keywords: Prophet Muhammad, Multicultural Education, Indonesia

Nur El-Islam, Volume 8, Nomor 2, Oktober 2021 


\begin{abstract}
Abstrak
Tulisan artikel ini bertujuan untuk menganalisis tentang pola Nabi Muhammad SAW dalam mengelola heterogenitas masyarakat Madinah secara toleran dan inklusif. Pada waktu yang bersamaan tulisan artikel ini juga bertujuan untuk me-landing-kan dan mengontekstualisasikan patronisme Nabi Muhammad dalam mengelola keragaman etnis budaya dan agama dalam konteks pendidikan agama di Indonesia. Disisi lain, tulisan artikel ini juga bertujuan untuk mencari titik temu antara Pancasila dan nilainilai ajaran Nabi Muhammad tentang toleransi beragama dalam piagam madinah. Metode analisis yang digunakan dalam tulisan artikel ini adalah studi kepustakaan yang menekankan analisis datanya pada beragam sumber literatur yang otoritatif. Ada beberapa temuan dalam tulisan artikel ini, yaitu: Pertama, posisi Nabi Muhammad sebagai kepala negara yang mampu menginisiasi lahirnya piagam Madinah justuru harus dilihat sebagai cikal bakal teoritis pendidikan multikulturalisme. Dalam rangka mewujudkan pendidikan multikulturalisme tersebut, Nabi Muhammad menjadikan teologi rahmatan lil 'alamin sebagai bahan bakar kognitif, afektif dan psikomotorik. Masyarakat Madinah yang plural diedukasi oleh Nabi Muhammad melalui nilai-nilai ajaran Islam yang universal. Keteladanan Nabi Muhammad dengan akhlaknya yang universal menjadi modal penting terwujudnya sikap toleransi dalam menyikapi multikulturalisme masyarakat Madinah. Kedua, Indonesia sebagai negara yang terdiri dari berbagai varian ras, suku, agama dan budaya menjadi relevan untuk me-landingkan nilai-nilai multikulturalisme tersebut. Ketiga, Pada waktu yang bersamaan Pancasila yang dijadikan sebagai falsafah hidup bernegara oleh masyarakat Indonesia selaras dengan ajaran-ajaran tentang toleransi di tengah kehidupan multikulturalisme masyarakat Madinah. Keragaman agama, suku dan budaya mampu disulam dan dirajut secara harmoni melalui nilai-nilai Islam yang universal sebagaimana yang tertuang dalam Pancasila.
\end{abstract}

Kata Kunci: Nabi Muhammad, Pendidikan Multikultural, Indonesia

\title{
A. Pendahuluan
}

Nabi Muhammad merupakan figur pemimpin negara yang berhasil melaksanakan kepemimpinan di tengah heterogenitas masyarakatnya. Muhammad dalam hal ini tidak hanya bertindak sebagai seorang kepala negara, melainkan ia juga memiliki peran sebagai pendidik. ${ }^{1}$ Keterampilan pedagogi yang dimilikinya membuat ia bijak dalam melaksanakan tugas kepemimpinan demi mewujudkan masyarakat yang toleran.

\footnotetext{
${ }^{1}$ Siti Rohmah dan M. Anas Budiarjo, Islam dalam Narasi Sejarah dan Peradaban (Malang:
} UB Press, 2018). 
Apalagi kini banyak radikalisme yang mengatasnamakan agama berwujud teror, pengeboman, aksi kekerasan dan berbagai bentuk kejahatan lain. Agama dinilai sebagai media yang tepat untuk memunculkan terorisme. Bahkan adanya gesekan kepentingan politik membuat agama menjadi sensitif dan mudah diadu domba, sehingga radikalisme semakin mengikis citra agama yang semestinya menyeru pada kedamaian. ${ }^{2}$

Perdamaian yang menjadi ajaran masing-masing agama seharusnya menjadi titik tekan untuk mewujudkan kehidupan inklusif. Keterbukaan manusia dalam menjalani kehidupan penting untuk dimiliki, mengingat Nabi Muhammad yang menunjukkan sikap adilnya dalam memimpin masyarakat Muslim dan Non-Muslim. Rasulullah Shalallahu 'alaihi wassalam memuliakan umatnya tanpa mendiskriminasi pemeluk agama lain. Usaha tersebut dilakukan dengan menetapkan kebijakan-kebijakan dengan tujuan yang saling menguntungkan, sehingga kehidupan pluralis dapat dicapai tanpa menciderai antar pihak. ${ }^{3}$

Kondisi kemajemukan masyarakat Madinah yang sangat multikultural mampu dirajut dan disulam secara harmonis oleh Rasulullah dalam konstitusi Piagam Madinahnya. Rasulullah memposisikan antara muslim dan non-muslim secara egaliter, supremasi hukum benar-benar ditegakkan tidak ada perbedaan sikap antara muslim dan non-muslim, bahkan nilai-nilai kemanusiaan sangat dijunjung tinggi. ${ }^{4} \mathrm{Hal}$ ini bisa dilihat dari belum tercapainya kepemimpinan politik yang disebabkan oleh kerasnya penolakan kaum quraisy terhadap ajaran Islam dan figur Nabi pada awal

2 Inayatul Ulya, "RADIKALISME ATAS NAMA AGAMA: TAFSIR HISTORIS KEPEMIMPINAN NABI MUHAMMAD DI MADINAH” 10, no. 1 (Februari 2016). h. 137

${ }^{3}$ Siti Rohmah dkk., "RECONTEXTUALIZATION OF ISLAMIC PEACE EDUCATION: A STUDY OF THE THEORY OF MOHAMMED ABU-NIMER IN THE INDONESIAN CONTEXT," Fieldwork in Religion 13, no. 2 (20 Desember 2018): 183-202, https://doi.org/10.1558/firn.37545.

${ }^{4}$ Lihat Thohir Luth, Moh Anas Kholish, dan Moh. Zainullah, Bernegara dalam Islam (Malang: UB Press, 2018); lihat juga, Mujaid Komkelo, Moh Anas Kholish, dan Fiqh Vredian Aulia Ali, Fiqh HAM: Ortodoksi dan Liberalisme Hak Asasi Manusia dalam Islam (Malang: Setara Press, 2015). 
perjuangannya. Namun, keberhasilan Nabi Muhammad menjadi seorang kepala negara di Madinah mencapai puncaknya setelah berhasil merebut kembali Kota Mekah secara militer, politik dan moral. ${ }^{5}$

Keberhasilan Nabi Muhammad dalam menyatukan masyarakat lintas agama membuatnya menjadi rujukan dalam kehidupan berbangsa dan bernegara. Rujukan tersebut berdasar pada adanya kepentingan umat yang majemuk. Sebab masyarakat saat ini terdiri dari berbagai latar belakang kesukuan dan agama yang berbeda. ${ }^{6}$ Selain itu, terdapat kecemburuan sosial ekonomi. Faktor-faktor tersebut menjadi pemicu munculnya konflik horizontal yang bahkan bisa tersulut kapan saja. ${ }^{7}$

Popularitas Muhammad sebagai pemimpin umat banyak disorot sebagai sosok teladan yang mampu mengakomodir banyaknya perbedaan. Namun, peranan Rasulullah dalam mengelola pendidikan demi menumbuhkan sikap toleran di tengah-tengah heterogenitas masyarakat belum begitu tereksplorasi. Padahal Nabi Muhammad dengan jiwa pendidikannya telah menanamkan nilai-nilai toleransi yang dibangun atas kesadaran yang inklusif. Sehingga dalam konteks inilah tulisan artikel ini bertujuan untuk menganalisis tentang pola Nabi Muhammad SAW dalam mengelola heterogenitas masyarakat Madinah secara toleran dan inklusif. Pada waktu yang bersamaan tulisan artikel ini juga bertujuan untuk me-landing-kan dan mengontekstualisasikan patronisme Nabi Muhammad dalam mengelola keragaman etnis budaya dan agama dalam konteks pendidikan agama di Indonesia. Disisi lain, tulisan artikel ini juga bertujuan untuk mencari titik temu antara Pancasila dan nilai-nilai

\footnotetext{
${ }^{5}$ Mohammad Kosim, "INSTITUSI POLITIK DI ZAMAN NABI MUHAMMAD SAW," Islamuna: Jurnal Studi Islam 2, no. 1 (5 Juni 2015): 1-15, https://doi.org/10.19105/islamuna.v2i1.651.

${ }^{6}$ Lihat, Moh Anas Kholish dan Khalid Rahman, Menjadi Muslim Nusantara Rahmatan Lil 'Alamiin (Yogyakarta: Laila Pustaka, 2015).

${ }^{7}$ Amrotun Sholikhin, "Piagam Madinah Konsensus Masyarakat Pluralis Madinah dan Makkah (Suatu Tinjauan Teori Konflik),” Jurnal Komunika 9, no. 1 (Juni 2015). h. 85
} 
ajaran Nabi Muhammad tentang toleransi beragama dalam piagam madinah

\section{B. Elan Vital Pendidikan Multikulturalisme di Indonesia}

Setidaknya, isu sentral tentang multikulturalisme sudah lama menjadi topik pembicaraan di Indonesia. Isu tersebut telah muncul empat dekade lalu di mana Indonesia, dengan negara kepulauannya telah menjadi diskursus berbagai kalangan perihal wacana keanekaragaman budaya, ras, suku, bahasa, dan agama. Begitu juga dengan isu pendidikan multikultural, hampir semua instansi (lembaga pendidikan dari berbagai tingkatan, instansi militer, pondok pesantren, dan lainnya), sama-sama menggagas pendidikan multikultural guna memajukan pendidikan sebagai bekal masa depan anak bangsa.

Secara historis, gagasan tentang pendidikan multikultural dapat ditelusuri melalui Civil Right Movement (Gerakan Hak-Hak Sipil), dimana para penggagas gerakan ini telah melibatkan banyak pihak, baik dari kalangan pakar pendidikan, para sarjana, para pendidik, akademisi, sejarawan, tokoh agama dan tokoh masyarakat untuk turut andil dalam merancang bangun pendidikan multikulutral.

Zakiyuddin Badhawi (2005) menyebutkan bahwa pada akhir dekade 70-an dan 80-an, terjadi beberapa gerakan yang berkaitan dengan pendidikan multikulural, yaitu gerakan perempuan yang memperoleh kekuatan dan pengaruh besar di lingkungan pendidikan. ${ }^{8}$ Pada saat itu, gerakan perempuan tersebut meskipun orientasinya mengarah pada kelas menengah dan peserta didiknya adalah dari kalangan kulit putih, namun gerakan ini memiliki daya juang yang kuat dalam menghubungkan perjuangan anti rasisme dengan perjuangan anti seksime yang kemudian keduanya mendapat perhatian serius dari para pemangku kebijakan dan khalayak luas.

\footnotetext{
${ }^{8}$ Lihat, Zakiyuddin Baidhawi, Pendidikan Agama Berwawasan Multikultural (Jakarta: Erlangga, 2005); Baca juga: Moh Anas Kholish, Menyemai Pendidikan Fikih Beyond The World: Menumbuhkan Living Toleransi di Tengah Kebinekaan Mazhab Fikih di Indonesia (Malang: Intrans dan Intelegensia, 2021).
} 
Dalam kasus tersebut, Zakiyuddin memberikan eksemplar pendidikan dua bahasa di Kuba (dilakukan oleh orang-orang Kuba pelarian akibat revolusi Castro) yang mengalami kemajuan signifikan di bidang pendidikan pada dekade 50-an. Orang-orang pelarian tersebut adalah kelompok minoritas yang tercatat istemewa, di mana pada saat itu orang-orang Meksiko-Amerika, Puerto Riko dan AsiaAmerika mengimplementasikan teori dan praktik bilingual education (dua bahasa). Sebagai bagian dari kultur, bahasa merupakan elemen penting bagi tumbuh kembangnya masyarakat melalui pola relasi dan interaksi, mengingat bahasa adalah salah satu pemersatu bangsa.

Dalam kaitannya dengan sejarah di atas, Zakiyuddin menuturkan bahwa pendidikan multikultural menyebut ketidakadilan adalah penindasan yang terlembagakan (institutionalized oppression) sebagaimana yang terjadi di Amerika Serikat pada dekade 70-an hinggan 80-an. Adanya ketidakadilan menjadi sumber kekuatan bagi kelompok-kelompok dan komunitas-komunitas yang tertindas. ${ }^{9} \mathrm{Hal}$ tersebut ditandai dengan ramainya diskursus tentang ketidakadilan dan mencapai puncaknya pada awal dekade 80 -an, di mana pendidikan mulitikulturalisme menjadi kritik ultimatum bagi Amerika Serikat yang saat itu bersikukuh mempertahankan supremasi internasionalnya dalam eskalasi perang dingin dan perang bebas.

Selanjutnya, lembaga pendidikan yang saat itu peserta didiknya sudah bercampur antar suku, etnis, dan bahasa mengalami diskriminasi dan tekanan serius dari kalangan menengah atas. Para peserta didik dari kulit berwarna (non kulit putih) yang berasal dari daerah-daerah kumuh dan tidak menggunakan bahasa Inggris sebagai bahasa ibu dicemooh dan dianggap lebih beresiko mengalami kegagalan hidup. Akan tetapi keadaan tersebut berangsur mereda saat perkembangan demografi di tahun 1985 mempublikasikan data bahwa selama abad 21 penduduk kulit berwarna semakin pesat. Hal tersebut

\footnotetext{
${ }^{9}$ Lihat, Zakiyuddin Baidhawy, Fikih Kebhinekaan: Pandangan Islam Indonesia tentang Umat, Kewargaan, dan Kepemimpinan Non-Muslim (Bandung: PT Mizan Pustaka, 2015); Baca juga: Moh Anas Kholish dan Ismail Suardi Wekke, "FIQH EDUCATION BASED ON INTERNAL TOLERANCE OF RELIGIOUS SOCIETY OF RELIGIOUS IDEOLOGY VARIANCE," International Journal of Pure and Applied Mathematics 119, no. 18 (2018).
} 
menjadi pertimbangan para pemangku kebijakan pendidikan dengan cara melakukan pemberuan sitem pendidikan berikut kurikulumnya dan mengintegrasikan nilai-nilai kebudayaan ke dalamnya.

Zakiyuddin menambahkan bawah pendidikan multikultural pada puncaknya adalah suatu cara untuk mengajarkan keragaman (teaching diversity) yang menghendaki sikap kritis dan penalaran yang jernih (rasionalitas etis), kecakapan intelektual, serta mengajarkan keterbukaan (inklusivisme), toleransi, pluralisme dimana terma kebudayaan menjadi poros kajiannya. ${ }^{10}$ Dalam aplikasinya, pendidikan multikultural mendorong pelibatan masyarakat sipil dari berbagai kultur (civil society), misalnya di dalam pengambilan kebijakan pemerintah dan kebijakan-kebijakan lainnya yang menyangkut hakhak sipil.

Di samping itu, pendidikan multikultural juga mengeksplorasi disiplin cultural studies, utamanya dalam aspek partikular dan universal. Dalam hal ini, pendidikan multikultural mengedepankan analisis perbandingan, etno-relatif, dan penilaian rasional terhadap berbagai perbedaan berikut persamaannya di dalam lingkup budaya masyarakat. Adanya relasi dan interrelasi antar keragaman budaya masyarakat adalah kunci dari sikap toleransi yang terdapat dalam pendidikan multikultural. Selanjutnya, perspektif-perspektif kultural dapat diintregasikan ke dalam diri seroang yang terpelajar dengan cara mengelaborasikan nilai-nilai kebudayaan yang ada dalam dirinya.

Pendidikan multikultural mengupayakan terciptanya iklim pendidikan inklusif yang mampu mengakomodir para peserta didik dari berbagai latar belakang tanpa pandang bulu. Para pengajar/guru kemudian bertugas untuk mengidentifikasi peserta didik dengan semua kelompok etnik dan kebudayaannya, pola interaksi, perbedaan karakter, dan pontensinya masing-masing. Dengan demikian, para guru dapat dengan mudah merumuskan cara mereduksi etnosentrisme, bulliying, stereotype, dan sejenisnya. Di samping itu

${ }^{10}$ Lihat, Baidhawy, Fikih Kebhinekaan: Pandangan Islam Indonesia tentang Umat, Kewargaan, dan Kepemimpinan Non-Muslim. 
para peserta didik didorong untuk belajar secara kolaboratif dan memecahkan masalah secara bersama-sama.

Semangat dari adanya pendidikan multikultur sebagaimana diuraikan di atas, bahwa para peserta didik baik dari tingkat sekolah dasar, menengah sampai perguruan tinggi diharapkan dapat tumbuh dalam dunia yang bebas dari syahwa sangka, bebas dari diskriminasi rasial, gender, penistaan agama, dan lain sebagainya.

Selanjutnya, untuk menjawab kebutuhan para peserta didik akan pendidikan multikultural, menurut Zakiyuddin ada dua paradigma untuk mengarahkan mereka. Pertama adalah paradigma toleransi, di mana para peserta didik diajak untuk saling berbagi pengalaman, saling mengerti dan tidak mencela satu sama lain. Dalam posisi ini, peserta didik yang hidup dalam setting sosial multikultur diarahkan untuk berbaur dalam kelompok lintas etnis dan diajarkan untuk belajar interaktif dan komunikatif, karena keberadaan mereka berbeda dengan anak-anak yang hidup di lingkungan sosial yang homogen.

Pada aras yang sama, paradigma pendidikan transformatif menekankan aspek pendidikan yang nir-kekerasan, anti bias sosial. Paradigma tersebut secara aplikatif diterapkan melalui pemberian tugas-tugas sekolah secara variatif sesuai latar belakang sosio-kultur para peserta didik. Dengan demikian, para siswa diharapkan mampu menjawab persoian-persoalan praksis yang dihadapinya, baik di lingkungan sekolah maupun di luar sekolah.

Peran pendidikan multikultural juga diharapkan mampu mengakomodir para orang tua atau wali murid, di samping juga diharapkan mampu memberikan dampak positif bagi masyarakat di sekitar sekolah. Di sisi lain, pemerintah sebagai pemangku kebijakan dapat terlibat secara aktif dalam mengontrol jalannya sistem pendidikan. Begitu pula keterlibatan para stakeholder seperti akademisi, tokoh agama, dan yang lainnya bersama-sama mendorong tebentuknya kesadaran kolektif akan koeksistensi, proeksistensi, dan 
merajut persaudaraan antar etnis, antar budaya dan antar pemeluk agama. $^{11}$

\section{Eksistensi Nabi Muhammad sebagai Seorang Pendidik Sejati}

Rasulullah dalam menjalankan titah kenabian dinilai tampil sebagai nabi yang paling sempurna di antara para nabi yang lain. Secara nasab atau keturunan ia memiliki keunggulan, selain itu juga dinilai memiliki kondisi fisik yang baik, dan jiwa serta nuraninya yang bersih. Sehingga Nabi Muhammad menjadi nabi yang pantas mendapat kemuliaan yang paling utama atas nabi-nabi lainnya. ${ }^{12}$

Nabi Muhammad dalam melakukan tugas sebagai pendidik tidak sepenuhnya berjalan secara lancar. Alih-alih mendapat mandat sebagai rasul dan menyebarkan Islam, jalan dakwahnya justru tersendat. Namun Muhammad tetap menunjukkan kegigihannya dalam berdakwah, meskipun mendapat tantangan yang sulit, yaitu berupa adanya penolakan dan serangan lainnya. Dakwah Nabi Muhammad di tengah-tengah masyarakat Quraisy Mekkah secara terus-menerus mendapat tekanan keras, seperti dianiaya, disiksa, dan diboikot secara sosial dan ekonomi. Penolakan tersebut juga muncul dengan pelabelan terhadap Muhammad yang dinilai sebagai tukang ramal, tukang sihir, bahkan orang gila. ${ }^{13}$

Mekah sebagai kota metropolis dan perdagangan memberi tantangan kompleks kepada Nabi Muhammad dalam mendidik masyarakat. Begitu pula dengan Madinah yang menjadi wilayah pertanian. Heterogenitas penduduk terdiri dari bangsa Arab dan Yahudi. Selanjutnya bangsa Arab terdiri dari 2 suku yaitu Aus dan Khazraj yang saling bertikai untuk memperebutkan pemimpin dalam

\footnotetext{
11 Baca: Moh. Anas Kholish dan Siti Rohmah, “MENJEMBATANI ANTARA MISI PROSELITISASI ISLAM-KRISTEN DAN KEHARUSAN MERAWAT KERUKUNAN: KONSTRUKSI TEOLOGIS FORUM KERUKUNAN UMAT BERAGAMA (FKUB) KOTA MALANG," Islamic Insights Journal 2, no. 1 (10 September 2020). h. 55-66, https://doi.org/10.21776/ub.iij.2020.002.01.4.

${ }^{12}$ Ibnul Jauzi, Al-Wafa: Kesempurnaan Pribadi Nabi Muhammad (Jakarta Timur: Pustaka al-Kautsar, 2018). h. 334

${ }^{13}$ Ira M. Lapidus, Sejarah Sosial Ummat Islam (Jakarta: Raja Grafindo Persada, 2000). h. 35
} 
masyarakat Madinah. Konflik tersebut menjadikan Madinah sebagai daerah yang tidak aman bahkan tidak kondusif. Sehingga selanjutnya, mereka membutuhkan piranti untuk meredakan konflik berkepanjangan tersebut. Pada tahap selanjutnya, Nabi Muhammad hadir dan mampu menjadi penengah atas pertikaian yang terjadi. Rasulullah mempersatukan masyarakat lintas suku, agama, dalam satu kesatuan wilayah yang disepakati bersama. ${ }^{14}$

Muhammad sebagai pemimpin Madinah menunjukkan spirit perjuangan yang dipenuhi jiwa untuk mendidik. Eksistensinya sebagai pendidik sejati dapat dilihat dari kesabarannya dalam menghadapi segala masalah yang datang. Penolakan beberapa masyarakat atas dirinya ia hadapi dengan keterbukaan. Setidaknya, penerimaan dan penolakan adalah proses yang wajar muncul dalam perjuangan melaksanakan dakwah. Proses penyampaian dakwah yang dilakukan Nabi Muhammad tentu juga menjadi bahan pelajaran penting bagi siapa saja yang mempelajari dan meneladaninya.

Eksistensi Nabi Muhammad sebagai pendidik sejati terbukti dari semangatnya dalam menjalankan misi dakwah. Nabi Muhammad mengawali perannya dalam mendidik dimulai dari ruang lingkup terkecil, yaitu keluarga. Ia mendidik umat secara bertahap, berawal secara sembunyi-sembunyi dengan mengajak istrinya, yaitu Khadijah untuk beriman dan menerima petunjuk-petunjuk dari Allah. Selanjutnya, Khadijah dalam sejarah dikenal sebagai orang pertama yang masuk Islam. Setelah Khadijah, beberapa orang terdekat Nabi Muhammad juga ikut mengimani ajaran Allah, seperti Ali bin Abi Thalib, Zaid bin Haritsah. Kemudian berlanjut kepada sahabat karib yang telah lama bergaul, yaitu Abu Bakar As-Siddiq. Lalu secara bertahap dakwah Muhammad meluas, namun terbatas pada golongan suku Quraisy. ${ }^{15}$

\footnotetext{
${ }^{14}$ Lihat, Harun Nasution, Teologi Islam (Jakarta: UI-Press, 1986).

${ }^{15}$ Agung Ibrahim Setiawan dan M. Al-Qautsar Pratama, "Karakteristik Pendidikan Islam Periode Nabi Muhammad Di Makkah dan Madinah," NALAR: Jurnal Peradaban dan Pemikiran Islam 2, no. 2 (31 Desember 2018): 130-37, https://doi.org/10.23971/njppi.v2i2.958.
} 
Pendidikan melalui dakwah yang dilakukan oleh Nabi Muhammad secara sembunyi-sembunyi merupakan langkah awal untuk menyebarkan Islam secara perlahan namun pasti. Orang-orang terdekat Muhammad yang mendapat pengaruh pada tahap selanjutnya dapat menjadi pendukung perjalanan panjang dalam melaksanakan misi dakwah sebagai bagian dari tanggung jawab pendidik. Kondisi tersebut mengindikasikan kepada manusia, khususnya sebagai seorang pendidik untuk mengawali tanggung jawab berdakwah secara perlahan tetapi pasti. Sebab tujuan dari berdakwah adalah menuntun pada jalan kebenaran yang sesungguhnya.

Dakwah secara terang-terangan selanjutnya dilakukan oleh Nabi Muhammad dengan sasaran yang lebih luas. Hal tersebut juga didukung dengan adanya jaminan perlindungan dari Allah Subhanahu wa ta'ala kepada Rasulullah Shalallahu 'alaihi wa salam melalui dan termaktub dalam Quran Surat Al-Hijr ayat 94 dan 95.

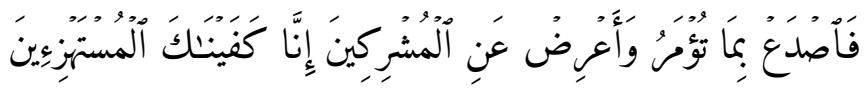

"Maka sampaikanlah olehmu secara terang-terangan segala apa yang diperintahkan (kepadamu) dan berpalinglah dari orang-orang yang musyrik."

"Sesungguhnya Kami memelihara kamu daripada (kejahatan) orangorang yang memperolok-olokkan (kamu)."

Secara tekstual, Nabi Muhammad telah mendapat perintah untuk berjuang dalam pendidikan melalui dakwah. Pada perintah tersebut Rasulullah diperintah untuk melakukan dakwah secara terang-terangan dan terbuka. Adanya tantangan mengenai penolakan dari pihak non-Muslim tidak perlu terlalu dipermasalahkan, karena Allah telah menjamin Muhammad sebagai pendidik sejati untuk melakukan dakwah dan melindunginya dari tindak kejahatan.

Hijrahnya Nabi Muhammad dan kaum muslimin ke Madinah menandakan adanya babak baru dalam perkembangan peradaban Islam. Pendidikan Islam yang dilaksanakan di Madinah merupakan kelanjutan pendidikan yang berada di Mekkah. Apabila pendidikan Islam di Mekkah menekankan pada penguatan dan penanaman aqidah dan akhlak. Maka selanjutnya pendidikan di Madinah menekankan 
pada pendidikan yang berhubungan dengan sosial kemasyarakatan dan politik dalam bernegara. Materi tersebut memiliki esensi ajaran tauhid yang mampu menginternilasisi dalam perilaku sosial masyarakat. ${ }^{16}$

Alasan secara sosial keberanian Muhammad melakukan dakwah juga karena dukungan dari para pengikut melalui jumlah sahabat Nabi yang semakin banyak. Adanya dukungan pendidikan secara terangterangan semakin menambah kekuatan yang lebih besar yang berpengaruh pada meningkatnya jumlah para pengikut dan pemeluk Islam secara masif. ${ }^{17}$

Aktivitas Muhammad sebagai pendidik terus dilakukan dengan menyebarluaskan ajaran agama Islam. Meskipun dalam beberapa kasus, peperangan atau jalan kekerasan juga menjadi bagian dari perjuangan Islam demi membela ataupun memenangkan diri. Namun, sesungguhnya penyebaran Islam melalui jalan pendidikan adalah dengan cinta dan perdamaian. Sebab perbedaan menjadi keniscayaan dalam menjalani hidup bersama.

Islam sebagai agama yang dibawa oleh Nabi Muhammad merupakan agama yang damai dan senantiasa selalu mengajarkan kasih sayang dan melakukan dakwah secara persuasif. Rasulullah memperkenalkan Islam dengan kasih sayang dan budi pekerti yang luhur. Namun Rasul mendapat titah untuk selalu berhati-hati dari orang-orang yang terus memusuhi Islam. ${ }^{18}$

Metodologi dalam menjalankan tanggung jawab sebagai pendidik dilaksanakan Nabi dengan menggunakan metode hiwar atau diskusi, beliau mendiskusikan segala hal demi mencapai kesepakatan bersama dan saling menerima. Muhammad juga terus mengajak pada

\footnotetext{
16 Wahyu Nurdiyati dkk., "SEJARAH SOSIAL PENDIDIKAN ISLAM PADA ERA KENABIAN,” HIKMAH: Jurnal Pendidikan Islam 8, no. 1 (11 Juni 2019): 3. h.6

${ }^{17}$ Setiawan dan Pratama, "Karakteristik Pendidikan Islam Periode Nabi Muhammad Di Makkah dan Madinah.”

${ }^{18}$ Retna Dwi, “DAKWAH ISLAM: ANTARA DAMAI DAN PERANG,”Al-Tsiqoh: Jurnal Ekonomi Dan Dakwah Islam 4, no. 1, April (5 April 2019). h. 1-2.
} 
kebaikan. Kemudian beliau berperilaku santun dan adil terhadap sesama, tanpa menggunakan unsur paksaan dalam berdakwah. ${ }^{19}$

Perang-perang yang terjadi di masa Rasulullah adalah bukan karena Nabi Muhammad ingin menyebarkan Islam dengan cara kekerasan, melainkan karena adanya sebab yang urgen dan mampu mencederai stabilitas kehidupan bersama. Seperti adanya motif untuk melawan serangan musuh yang terlihat secara kasat mata, seperti perang Uhud, perang Khandaq. Lalu mematahkan serangan musuh seperti perang Khaibar. Posisi kaum Muslimin pada saat itu adalah defensif dan tidak agresif. Sehingga adanya perang atas nama Islam bukan berarti menjadi generalisir atas ajaran Nabi yang keras. ${ }^{20}$

Nabi Muhammad dalam mendidik tidak mengajarkan pada sikap untuk memerangi siapapun dan mengeksploitasi apapun. Eksistensi beliau sebagai pendidik sejati terbukti dari adanya sikap terbuka dalam menerima perbedaan. Karena keragaman diyakini sebagai sunatullah. Namun bukan berarti misi dakwah harus berhenti dan tidak bergerak secara progresif. Kegiatan berdakwah adalah aktivitas penting dalam menjalankan tugas sebagai sosok pendidik sejati. Pendidik yang mampu memberi contoh dan teladan yang baik dalam mendidik masyarakat.

Pendidikan berbasis keluarga juga ditekankan oleh Nabi sebagai langkah awal menanamkan sikap toleransi. Sebab setiap anak diyakini lahir dalam keadaan fitrah. Orang tualah yang menjadikan anak tersebut menjadi beragama Yahudi, Nasrani atau Majusi. ${ }^{21}$ Sehingga menjadi sebuah keharusan bahwa dalam melakukan tugas sebagai pendidik untuk mengajarkan ilmu akidah sebagai salah satu unsur pembangun jiwa yang kuat di dalam masyarakat. ${ }^{22}$

Kekuatan masyarakat dalam basis multikultural tentu memiliki tantangan dan peluang yang perlu dianalisis. Karena basis

\footnotetext{
${ }^{19}$ Dwi, h. 7-8.

${ }^{20}$ Dwi, h. 8.

${ }^{21}$ Lihat, Al-Imamal-Hafidz Abi 'Abdillah Ibn Isma'il Al-Bukhari, al-Jana "iz, Bab ma Qila Aulad al-Musyarikin (Libanon: Beirut, 2003). h. 182 No. 1296

${ }^{22}$ Muhammad Khairi Mahyuddin, "Tasawuf dan Peembangunan Rohani di Kalangan Masyarakat,” Jurnal Ushuluddin Adab Dan Dakwah 1, no. 2 (2018). h. 40-230
} 
multikultural memiliki ancaman konflik yang dapat terjadi kapan saja, sehingga perlu untuk memahami kondisi masyarakat yang dinamis. Tantangan dakwah dalam melakukan tugas sebagai pendidik yang dilakukan Nabi Muhammad pada masyarakat multikultural di Madinah adalah salah satu contoh pembacaan realitas yang patut dipahami.

Tantangan dakwah pada masyarakat multikultual setidaknya juga terjadi di beberapa daerah lain, seperti di Kalimantan Tengah yang mendapat tantangan dari faktor internal berupa dai yang berasal dari daerah luar, mad'u atau masyarakat yang tidak bisa menerima materi, pendekatan, metode, dan media dakwah yang tidak disukai muslim setempat. Sedangkan faktor eksternal berupa adanya kristenisasi serta dominasi politik dari kaum minoritas dan lemahnya dukungan pemerintah terhadap dukungan dakwah, sehingga pendidikan Islam berjalan lambat. ${ }^{23}$ Tantangan lain berhasil diatasi oleh gerakan dakwah Islam multikultural pada komunitas Sunda, Arab Alawi dan Arab Irsyadi yang memilih pendakwah yang kompeten, yaitu Kyai, Ajengan, Habib, Syarif dan Sayid yang menghargai adanya perbedaan. ${ }^{24}$ Selanjutnya tugas pendidikan juga dilakukan pada masyarakat terpencil dengan dakwah bil hal sebagai langkah untuk meningkatkan taraf kehidupan masyarakat. Hal itu dilakukan dengan memberdayakan masyarakat sehingga menjadi lebih kuat, sehingga mereka dapat menguasai kehidupannya. ${ }^{25}$ Lalu dakwah inklusif dilakukan di Parepare dengan mengakui keragaman sebagai sunnatullah. Kesadaran atas perbedaan merupakan takdir Ilahi yang

\footnotetext{
${ }^{23}$ Abdul Azis dan Nor Muslim, "TANTANGAN DAKWAH PADA MASYARAKAT MULTIKULTURAL DI KALIMANTAN TENGAH,” Wardah 19, no. 2 (Desember 2018). h. 34-120

${ }^{24}$ Sukriadi Sambas, Indira Sabet, dan Ratna Dewi, "DAKWAH ISLAM MULTIKULTURAL PADA KOMUNITAS SUNDA, ARAB ALAWI DAN ARAB IRSYADI,” Anida (Aktualisasi Nuansa Ilmu Dakwah) 19, no. 1 (25 Juni 2019), https://doi.org/10.15575/anida.v19i1.5067. h. 84-104

${ }^{25}$ Muhammad Ahnu Idris, "DAKWAH PADA MASYARAKAT DAERAH TERPENCIL: METODE DA'WAH BI AL-HAL SEBAGAI UPAYA MENINGKATKAN TARAF KEHIDUPAN MAD’U,” 'Ulumuna: Jurnal Ilmu Keilsman 3, no. 1 (2018). h. 77-81
} 
bermuara pada bentuk pemikiran dan tindakan arif serta bijaksana terhadap pluralitas. ${ }^{26}$

Pendidik-pendidik tersebut dalam melakukan tugas berdakwah mengalami tantangan dan peluang. Hadirnya tantangan dari masyarakat perlu dipahami. Karena Rasulullah telah membaca realitas masyarakat yang jamak. Pada tahap yang sama, peluang dalam membangun peradaban menjadi terbuka. Sehingga peradaban inklusif dapat dicapai dengan melalui pendidikan berbasis multikulturalisme, sebagaimana langkah-langkah yang telah dilakukan oleh Nabi Muhammad Shalallahu 'alaihi wassalam.

Materi-materi yang diajarkan oleh Rasulullah dalam mengembangkan kompetensi pendidiknya adalah memuat pengajaran Islam yang berisikan nilai-nilai ketauhidan, ibadah, akhlak, syariah, sosial, budaya, dan tata kelola bernegara. Lahirnya sistem pendidikan Islam seperti demikian menjadi tanda bahwa Allah telah mempersiapkan manusia agar kembali kepada fitrahnya, yaitu sebagai khalifah fil ard yang memiliki tanggung jawab untuk menjunjung tinggi nilai-nilai kebenaran. Selain itu, manusia memiliki kewajiban untuk beriman dan berusaha menjaga bumi dari adanya kerusakan. Muhammad sebagai manusia yang mendapat mandat dari Allah bertugas untuk terus menyeru dan membimbing manusia melalui jalan pendidikan dan pengajaran. Hal itu dilakukan agar manusia dapat menjadi khalifah di bumi, beriman kepada Allah dan menjalankan kewajiban beribadah kepada Allah. ${ }^{27}$

Konsep dasar pendidikan Islam di Madinah menyentuh pada aspek ketuhanan dan religius. Selain itu pendidikan juga menyentuh filsafat tentang hakikat manusia dan ilmu pengetahuan. Manusia yang memiliki hakikat sebagai makhluk ciptaan Allah memiliki unsur jasmani dan rohani yang berpotensi untuk mengembangkan diri sebagai khalifah di dunia ini. Hakikat ilmu pengetahuan adalah berasal dari Allah, sebab bersumber pada wahyu, alam seisinya, fenomena

\footnotetext{
${ }^{26}$ Iskandar Iskandar dkk., "DAKWAH INKLUSIF DI KOTA PAREPARE,” KOMUNIDA : Media Komunikasi dan Dakwah 8, no. 2 (Desember 2018), https://doi.org/10.35905/komunida.v8i2.632. h. 88-180

${ }^{27}$ Nurdiyati dkk., “Sejarah Sosial Pendidikan Islam Pada Era Kenabian,” 1.
} 
sosial, intuisi, kemampuan berpikir, dan seluruh sumber lainnya. Nabi sebagai pendidik juga berfokus dalam membentuk akhlak umat. Langkah untuk mewujudkan tujuan yang luhur tersebut dilakukan Muhammad dengan mengajarkan Al-Quran. Kitab suci umat Islam itu diajarkan dengan 3 cara. Pertama, baca tulis, hal ini didasarkan pada kebiasaan masyarakat yang sering membaca dan melantunkan syairsyair. Kedua, menghafal ayat-ayat al-Quran, hal ini didukung dengan kentalnya tradisi lisan. Ketiga, pemahaman terhadap al-Quran. Hal ini dilakukan untuk mendalami isi kitab suci umat Islam agar ternanam dalam kalbu masyarakat, sehingga mampu mengubah pola pikir menjadi lebih terbuka. ${ }^{28} 29$

Metode Rasulullah dalam menjalankan tugas sebagai seorang pendidik adalah dengan tanya jawab, dialog, diskusi. Metode tersebut dilakukan ketika mengajar ilmu pengetahuan yang berkaitan dengan keimanan. Selanjutnya adalah metode demostrasi yang digunakan Nabi Muhammad saat memberikan pengajaran dengan memberikan contoh langsung. Seperti wudhu, shalat, puasa, haji, zakat, dan lainlain. Kemudian metode kisah-kisah yang banyak memuat sejarah maupun masalah sosial lain dengan tujuan mengambil ibrah atas kisah-kisah tersebut. ${ }^{30}$ Metode paling penting dalam bertugas sebagai pendidik adalah memposisikan diri sebagai teladan, karena figur nabi menjadi contoh dalam beribadah dan model dalam akhlak untuk menjalani kehidupan. ${ }^{31}$

Lembaga pendidikan juga penting kehadirannya untuk mendukung pendidik dalam melaksanakan tugasnya. Nabi Muhammad mendidik dengan bertempat di rumah, masjid, dan kuttab. Rumah adalah tempat pertama kali Rasul menyelenggarakan pendidik, yaitu di rumah Al-Arqam saat masa awal menyampaikan wahyu Allah.

\footnotetext{
${ }^{28}$ Abuddin Nata, Ilmu Pendidikan Islam (Jakarta: Kencana Pranada Media Group, 2010). h. 46-69

${ }^{29}$ et.all Zuhairini, Sejarah Pendidikan Islam (Jakarta: Dirjen Binbaga Islam Depag RI, 1986). h. 34-54

${ }^{30}$ Mamud Yunus, Sejarah Pendidikan Islam (Purwokerto: Hidakarya Agung, 1992). h. 2225

${ }^{31}$ Nurdiyati dkk., “Sejarah Sosial Pendidikan Islam Pada Era Kenabian.” h. 8-7
} 
Kemudian masjid selain sebagai tempat ibadah juga digunakan sebagai kajian ilmu pengetahuan dan penyebaran dakwah. Selanjutnya, kuttab merupakan tempat belajar menulis dan membaca yang dipakai sebagai lokasi untuk mengajarkan Al-Quran. ${ }^{32}$

Dengan demikian, eksistensi Nabi Muhammad sebagai seorang pendidik sejati tidak dapat terlepas dari adanya beberapa perangkat yang dibutuhkan dalam mendidik. Yaitu ketersediaan materi, metode, sarana dan prasana sebagai piranti penting dalam mendidik masyarakat. Selain itu, semangat perjuangan Nabi Muhammad juga menjadi faktor urgen dalam mengembangkan diri sebagai pendidik yang mampu memberikan pengaruh baik dan progresif kepada umat.

\section{Potret Heterogenitas Masyarakat Madinah}

Melalui piagam madinah, Nabi Muhammad menunjukkan bahwa perlu sikap terbuka untuk mengelola aspek-aspek kehidupan, khususnya dalam hal keberagamaan dan kebijakan politik terhadap masyarakat plural. Heterogenitas masyarakat Madinah menjadi bukti atas demokratisnya pemikiran dan kebijakan Nabi dalam melakukan tanggung jawab sebagai pemimpin negara dan pemimpin agama. Rasul tidak hanya menyentuh pada sisi keagamaan semata, melainkan juga menyelesaikan permasalahan dalam berbangsa dan bernegara.

Toleransi masyarakat Madinah senada dengan toleransi Islam dalam beragama. Sikap inklusif yang ada terrepresentasi dari tidak adanya paksaan untuk memeluk agama Islam. Toleransi yang terjadi mengajarkan pada ajaran hidup berdampingan dalam bermasyarakat dan bernegara, asalkan tidak memerangi satu sama lain. Sehingga Islam mendapatkan perintah untuk berbuat baik dan menjaga hak-hak mereka. ${ }^{33}$

Islam dalam hal ini bersikap terbuka dengan kondisi kemajemukan. Pluralitas dipandang sebagai salah satu sunatullah di alam ini. Adanya keanekaragaman manusia perlu disikapi secara

\footnotetext{
${ }^{32}$ Nurdiyati dkk., 9-10.

${ }^{33}$ Muhammad Yasir, “MAKNA TOLERANSI DALAM AL-QUR'AN,” Jurnal Ushuluddin 22, no. 2 (1 Desember 2014)h. 170-80, https://doi.org/10.24014/jush.v22i2.734.
} 
positif dan konstruktif sebagai upaya mewujudkan keadaan damai. Pluralisme diyakini sebagai spirit dalam mencapai kedamaian dan menuju kemaslahatan kehidupan manusia. ${ }^{34}$

Potret heterogenitas masyarakat Madinah direpresentasikan melalui keragaman agama yang saling menghormati ragam keyakinan. Selain itu, formasi masyarakat Madinah terdiri dari jamaknya budaya yang mencirikan kemajemukan kota tersebut. Kedatangan Nabi yang disambut baik dan diakui pula sebagai pemimpin negara membuat Madinah tumbuh sebagai kota yang inklusif dan berperadaban.

Peradaban Madinah terkonstruk dari adanya hubungan dialogis antar umat beragama melalui dialog yang dilakukan untuk mencapai kerukunan umat lintas agama. ${ }^{35} \mathrm{Nabi}$ Muhammad dalam suasana kerukunan menjadi sosok ideal yang mampu menumbuhkan sikap masyarakat untuk saling menerima perbedaan. Tak ayal, permasalahan mengenai kehidupan beragama, kondisi ekonomi, keadilan sosial dan politik mampu dikelola oleh Muhammad dengan menjunjung tinggi nilai-nilai kemanusiaan.

Madinah menjadi tempat komunitas Islam yang bebas dan merdeka di bawah kepemimpinan Nabi Muhammad. Pengikut Rasulullah terdiri umat yang datang dari Makkah, mereka disebut kaum Muhajirin. Selanjutnya adalah penduduk Madinah yang telah memeluk Islam. Merekalah yang mengundang Nabi Muhammad untuk hijrah ke Madinah dan disebut sebagai kaum Anshar. Eksistensi masyarakat Islam di Madinah didapat karena adanya keterbukaan dari masyarakat majemuk. ${ }^{36}$ Sebab di antara penduduk Madinah terdapat kaum Yahudi dan sisa-sisa suku Arab yang belum menerima Islam. Muhammad menjadi kepala negara yang dinilai bijak sebab mampu menetapkan konstitusi yang dapat diterima semua pihak sebagai

\footnotetext{
${ }^{34}$ Yasir, 177.

${ }^{35}$ Abu (ed.) Zahra, Politik Demi Tuhan: Nasionalisme Religius di Indonesia, (Bandung: Pustaka Hidayah, 1999). h. 31

${ }^{36}$ Munawir Sjadzali, Islam dan Tata Negara (Jakarta: UI Press, 1990). h. 10
} 
undang-undang dasar. Undang-undang tersebut menjadi teks tertulis yang mengatur kehidupan dan hubungan lintas umat yang berbeda. ${ }^{37}$

Kota Madinah adalah wilayah yang siap dengan basis dakwah. Hal itu juga didukung oleh masyarakat yang lebih dulu mengenal Nabi Muhammad sebelum bertemu dengan beliau. Bahkan, yang mengenalkan tentang Muhammad adalah orang-orang Yahudi yang berdatangan ke kampung halaman mereka. Sehingga pada tahap secara kontinyu, Rasulullah memiliki patronasi dalam mengelola masyarakat. Hal itu didukung oleh amanat yang menjadikan Muhammad sebagai penguasa dan juga menjamin keselamatan nonMuslim. ${ }^{38}$

Heterogenitas masyarakat madinah menjadi model yang dapat diteladani. Pasalnya orang-orang bersikap terbuka dalam kondisi berbeda. Keragaman tersebut terdiri dari perbedaan agama, suku, budaya. Tentu pemikiran masyarakat yang terbuka dan peran Nabi Muhammad memiliki hubungan penting dalam mengelola Madinah sebagai kota berperadaban.

Bahkan dalam sejarah kenabian, era Madinah dianggap sebagai era yang penting, karena menjadi intisari sirah nabawiyah. Hal tersebut didukung oleh dilakukannya dasar perhitungan tahun Islam. Pada masa Khalifah Umar bin Al-Khattab radhiyallahuanhu disepakati bahwa hitungan Islam dimulai saat peristiwa hijrah Nabi Muhammad ke Madinah. Keputusan tersebut juga menjadi keputusan politis dalam narasi sejarah. Selain itu, ulama menyepakati bahwa ayat-ayat yang turun di Madinah mengandung hukum-hukum syariah, sehingga pelaksanaan ibadah mendapat tuntunan yang lebih detail. Seperti shalat, puasa, haji, jinayat, dan perang. ${ }^{39}$

Realitas di Madinah yang menguatkan adanya keragaman adalah bahwa tidak semua penduduk Madinah muslim. Dalam hal ini Islam menjadi mayoritas. Kemudian Yahudi menjadi agama mayoritas

\footnotetext{
37 Ulya, "Radikalisme Atas Nama Agama: Tafsir Historis Kepemimpinan Nabi Muhammad di Madinah.” h. 116

${ }^{38}$ Ahmad Sarwat, Madinah Era Kenabian: Kajian Kritis Sirah Nabawiyah Madinah dalam Agama, Sosial dan Politik (Jakarta: Rumah Fiqih Publishing, 2018). h. 11

${ }^{39}$ Sarwat. h. 13-14
} 
kedua. Kemudian semua agama lain juga tidak dinafikan keberadaanya, malah diakui eksistensinya. Di Madinah dalam menetapkan hukum adalah sesuai agama masing-masing, Muslim menggunakan Al-Quran dan Yahudi menggunakan Taurat. Selanjutnya, masyarakat Madinah yang berbeda-beda tersebut secara politis bersatu untuk saling membela. Hal tersebut dilakukan untuk membentengi diri dari serangan ataupun kekuatan dari luar. Lalu secara muamalat, meskipun berbeda agama, mereka saling berjualbeli, melakukan perdagangan, melakukan hutang-piutang, praktik gadai, sewa, pinjam, bahkan murabahah dan mudharabah. ${ }^{40}$

Potret heterogenitas masyarakat Madinah menjadi penting untuk dipahami. Karena kondisi masyarakat lintas kelas yang mampu menembus batas perbedaan. Distingsi yang ada dalam masyarakat Madinah menjadi sebuah keniscayaan, namun bukan berarti perpecahan menjadi halal. Justru persatuan menjadi kunci utama dalam memperjuangkan spirit kemanusiaan.

\section{E. Spirit Profetik Nabi Muhammad melalui Piagam Madinah dalam Mengelola Kehidupan Masyarakat Madinah yang Multikultural}

Keberhasilan Nabi Muhammad dalam mewujudkan masyarakat yang toleran merupakan bukti bahwa sosoknya menjadi simbol keberhasilan dalam membendung lahirnya radikalisme. Kebijakan yang dikeluarkan oleh Muhammad dilakukan melalui kebijakan dan pe ndekatan dalam berbagai peran. Ia menjadi pemimpin negara yang menggunakan otoritas kekuasaannya, yaitu dengan menggunakan kecakapan hubungan sosial melalui bentuk keteladanan yang baik, saling menghargai, saling menghormati kemajemukan, bersikap egaliter, berperadaban dan berilmu pengetahuan yang tinggi. ${ }^{41}$

Manajemen pendidikan Muhammad dalam melahirkan piagam Madinah menggunakan analisis yang mendalam. Rasul terbukti membaca kemungkinan-kemungkinan yang terjadi, sehingga

\footnotetext{
${ }^{40}$ Sarwat. h. 14-15

41 Ulya, "Radikalisme Atas Nama Agama: Tafsir Historis Kepemimpinan Nabi Muhammad di Madinah.” h. 137
} 
pandangannya adalah visioner, jauh ke depan. Pemikiran yang maju dan progresif membuat Nabi Muhammad mampu mengelola pendidikan secara inklusif demi mewujudkan peradaban yang maju. Usaha Rasulullah dalam memajukan umat didukung oleh disepakatinya perjanjian dalam piagam madinah yang menjadi tanda diterimanya keragaman.

Piagam madinah memuat pesan yang sangat berharga dalam mengembangkan konstitusi yang demokratis. Piagam madinah mampu mengakomodir kelompok-kelompok, khususnya kaum Yahudi dan Pagan. Piagam Madinah merupakan komitmen bersama untuk hidup dalam kebersamaan secara damai. Semua pihak saling bahumembahu untuk membangun kota Madinah sebagao kota yang berperadaban dan berkeadaban. Madinah menjadi prototip dari negara-negara yang menekankan kemajuan dan peradaban dalam Islam. Sehingga sepatutnya Madinah menjadi inspirasi untuk mengembangkan politik yang menegakkan moral, memajukan peradaban dan memihak kepada kepentingan bersama. Semua kelompok patut untuk diakomodir secara lintas latar belakang suku, agama, ras. ${ }^{42}$

Sistem kenegaraan yang terangkum dalam Piagam Madinah menjadi faktor penting dalam manajemen pendidikan Nabi Muhammad. Piagam madinah menjadi bukti bersatunya kalangan mukminin dan muslimin yang menggabungkan diri dan berjuang bersama. Pasal-pasal dalam piagam madinah menunjukkan adanya kesepakatan untuk satu umat, menyerukan untuk bersikap seperti pada muhajirin, Quraisy, Bani Auf, Bani Sa'idah, Bani Al-Hars, Bani Jusyam, Bani An-Najjar, Bani 'Amr bin 'Awf, Bani Al-Nabit, Bani Al'Aws. Kemudian mukminin mendapat amanat untuk membantu tebusan atau diyat, menentang kezaliman, kejahatan secara bersama, tidak diperkenankan membunuh orang kafir, membela yang lemah, mewujudkan perdamaian, tidak berselisih. ${ }^{43}$

\footnotetext{
${ }^{42}$ Zuhairi Misrawi, Madinah: Kota Suci, Piagam Madinah, dan Teladan Muhammad SAW (Jakarta: Kompas, 2009). h. 295

${ }^{43}$ Sarwat, Madinah Era Kenabian: Kajian Kritis Sirah Nabawiyah Madinah dalam Agama, Sosial dan Politik. h. 35-43
} 
Selanjutnya, dalam piagam madinah dijelaskan bahwa Yahudi dari Bani 'Awf adalah satu umat dengan mukminin. Begitu juga dengan Bani Najjar, Hars, Saidah, Jusyam, Aus, Tsa'labah, Jafnah, Syuthaibah, Mawali Tsa'labah, kerabat Yahudi. Tidak seorangpun dibenarkan untuk berperang kecuali dengan seizin Nabi Muhammad. Mereka diperintahkan untuk saling tolong menolong. Lalu menegaskan bahwa Yastrib adalah tanah haram (suci) bagi warga piagam Madinah tersebut. Semua yang mendukung piagam Madinah berhak mendapat perdamaian. Perlakuan baik perlu ditujukan demi kepentingan bersama. Piagam Madinah menjamin kepentingan bersama untuk mewujudkan perdamaian, keamanan, dan stabilitas kehidupan berbangsa. ${ }^{44}$

Piagam madinah hadir demi meredam faktor-faktor kemungkinan konflik yang dapat muncul kapan saja. Sebab adanya perbedaan-perbedaan yang ada secara historis telah menyebabkan peperangan dan menghalalkan pembunuhan atas nama agama dan lain sebagainya. Perebutan kekuasaan juga menjadi faktor yang memicu timbulnya peperangan, ketidakharmonisan dalam masyarakat. Oleh karena itu, Muhammad melalui piagam madinah berusaha menyelesaikan permasalahan masyarakat secara profesional. Keputusan Nabi Muhammad yang bijaksana tersebut terbukti mendapat dukungan dari masyarakat, baik dari kalangan Muslim, maupun selainnya.

Nabi Muhammad berhasil memberikan dokumen sejarah yang paling modern pada zamannya. Piagam madinah berhasil mengatur kehidupan umat beragama dari multi-budaya dan multi-agama. Piagam tersebut menjadi konstitusi yang mengatur berbagai kepentingan dari berbagai lapis agama dan keompok agar dapat semua lapisan kalangan masyarakat dapat melakukan semua aktivitas dengan baik. Tujuannya adalah adanya ketenteraman hidup dalam bingkai kepemimpinan Nabi Muhammad Shalallahu 'alaihi wassalam. Muhammad yang kharismatik dan pluralistik mampu menjalankan kepemimpinannya dengan melampaui batas-batas kebangsaan,

\footnotetext{
${ }^{44}$ Sarwat. h. 43-49
} 
wilayah geografis, dan aspek kemanusiaan. Piagam madinah dihadirkan oleh Muhammad dan menjadi inspirasi berkembangnya masyarakat madani dan masyarakat sipil (civil society). ${ }^{45}$

Pengelolaan pendidikan yang dilakukan oleh Nabi Muhammad adalah melakukan pengamatan mendalam, yaitu melihat kondisi masyarakatnya, khususnya Madinah. Hasil dari observasi tersebut membuat Rasulullah mampu merumuskan kebijakan-kebijakan yang kemudian tertuang dalam piagam madinah. Sehingga piagam Madinah bukan hanya sekedar undang-undang yang membela kepentingan mayoritas, melainkan sebuah kebijakan yang mampu menyatukan kekuatan antara mayoritas dan minoritas dalam masyarakat.

Perihal hak minoritas telah dipraktekkan oleh Nabi Muhammad dalam memimpin Negara Madinah dan juga telah dikukuhkan dalam bentuk the constitution of medina. Pemerintahan yang dijalankan oleh Nabi dijalankan dengan baik dan komprehensif. Orang-orang non Muslim diperlakukan secara baik dan bahkan menguasai pemerintahan serta dalam sektor ilmu pengetahuan. Sehingga hal tersebut menjadi bukti Islam yang bertanggung jawab terhadap hakhak minoritas. ${ }^{46}$

Pendidikan yang dilakukan oleh Muhammad dalam melahirkan piagam Madinah juga terlihat dari kemampuannya dalam memetakan masyarakat. Kelas-kelas yang ada dalam masyarakat menjadi data yang kemudian dibaca Nabi sebagai bahan pertimbangan untuk melakukan kebijakan. Bahkan Nabi Muhammad melakukan pendidikan untuk semua. Artinya, sikap pendidik yang dimiliki oleh Rasul adalah terbuka, bukan tertutup, khususnya dalam membaca adanya kompleksitas perbedaan.

Manajemen pendidikan yang dilakukan Nabi di Madinah adalah meluaskan cakupan kurikulum pendidikan, dari yang awalnya menekankan pada pemahaman tauhid dan Alquran, meluas pada

\footnotetext{
${ }^{45}$ Nandang Hmz, "DARI PIAGAM MADINAH KE PLURALITAS KEPEMIMPINAN NABI MUHAMMAD SAW,” dalam Prosiding SNaPP: Sosial, Ekonomi dan Humaniora, vol. 4, 1, 2018. h. 82-475

${ }^{46}$ Havis Aravik, "HAK MINORITAS DALAM KONTEKS ISLAM," Mizan: Journal of Islamic Law 5, no. 1 (14 Juni 2018), https://doi.org/10.32507/mizan.v5i1. h. 195.
} 
materi pendidikan akhlak, amal ibadah, kehidupan sosial kemasyarakatan, ekonomi, kesehatan, dan kehidupan bernegara. Rasulullah menerapkan pendidikan Islam yang disesuaikan dengan kondisi sosial masyarakat, sehingga pendidikan dapat diterima dan diamalkan. ${ }^{47}$

Sahabat-sahabat Nabi Muhammad turut menjadi aktor penting dalam mengembangkan pendidikan inklusif. Gerakan yang dilakukan oleh umat Nabi juga terpengaruh oleh keteladanan dari Nabi yang mampu mengatur seluruh masyarakat untuk hidup bersama dalam nuansa multikultural. Sehingga secara tidak langsung Nabi Muhammad telah mengatur sistem pendidikan yang menyebar baik secara masif maupun pengaruh perorangan.

Manajemen pendidikan secara kultural dan struktural dilakukan Nabi Muhammad, mengingat posisinya di Madinah sebagai agamawan dan negarawan. Penggunaan wewenang sebagai negarawan untuk kepentingan penyebaran pendidikan Islam dinilai sebagai keniscayaan. ${ }^{48}$ Diterimanya sosok Muhammad sebagai pendidik dan pemimpin tentu menjadi keuntungan tersendiri dalam misi menanamkan sikap toleran.

Keberhasilan Muhammad dalam mendidik terjadi atas dukungan masyarakat. Sehingga Rasulullah turut sukses dan mengantarkan Islam menjadi sebuah peradaban yang unggul di dunia. Islam tidak hanya menjadi agama ritualistik, namun menjadi sistem hidup yang mengatur seluruh warga negara. Tidak hanya perkara akidah, ibadah, makanan, pakaian, pernikahan, melainkan juga meliputi sistem sosial, budaya, ekonomi, politik, pendidikan, kesehatan, keamanan, militer, sanksi, dan hubungan negara dengan negeri lain. ${ }^{49}$

\footnotetext{
47 Setiawan dan Pratama, “Karakteristik Pendidikan Islam Periode Nabi Muhammad Di Makkah dan Madinah.” h. 14-17

${ }^{48}$ Lihat, Abdullah, "KOMPLEMENTARITAS DAKWAH KULTURAL DAN STRUKTURAL," Jurnal Pemberdayaan Masyarakat 4, no. 4 (6 November 2018), http://jurnal.uinsu.ac.id/index.php/PEMAS/article/view/2625.

${ }^{49}$ Hasan Basri, "MANAJEMEN DAKWAH NABI MUHAMMAD SAW DI MADINAH," $A l-$ MUNZIR 8, no. 2 (15 Maret 2018), https://doi.org/10.31332/am.v8i2. 743. h. 76-176
} 
Manajemen pendidikan yang dilakukan oleh Nabi Muhammad dalam melahirkan Piagam Madinah adalah dengan melakukan pengamatan mendalam untuk memahami kondisi masyarakat. Ketika kondisi masyarakat Madinah dipahami, maka pemetaannya dapat dilakukan melalui kebijakan-kebijakan yang adil, tidak mendiskriminasi minoritas, bersatu, hidup bersama dan berdampingan secara damai, serta menekankan pada spirit kemanusiaan.

Nabi Muhammad merupakan teladan yang mampu memimpin umat manusia. Kepemimpinan Muhammad patut dijadikan sebagai model ideal dalam hal kepemimpinan umat, karena Rasulullah dikaruniai 4 sifat utama. Pertama, Sidiq yang berarti jujur dalam segala perkataan dan perbuatan. Kedua, amanah yang menjadi ciri bahwa Nabi Muhammad adalah teladan yang selalu dapat dipercaya, khususnya dalam menjaga tanggung jawab. Ketiga, tabligh yang berarti menyampaikan segala sesuatu tentang kebaikan dan keburukan kepada rakyatnya. Keempat, yaitu fathonah yang berarti cerdas, Nabi Muhammad merupakan sosok cerdas yang mengelola masyarakat sehingga dapat hidup rukun secara bersama-sama. ${ }^{50}$

Manajemen pendidikan yang dilakukan oleh Nabi Muhammad tentu menjadi teladan bagi penyelenggaraan pendidikan Islam. Manajemen pendidikan Islam menjadi salah satu faktor keberhasilan pelaksanaan pendidikan, baik secara teoritis-konseptual ataupun dalam tataran realitas-ekspektasional. Manajemen pendidikan Islam merupakan kegiatan mengelola dan menyiasati pencapaian tujuan utama, yaitu bermuara pada ajaran Al-Quran dan Hadits.

Ajaran Islam dalam rumusan definitif terkait dengan manajemen pendidikan Islam mencakup pada 3 sisi. Pertama, ontologi sebagai objek pengelolaan, yaitu berupa lembaga pendidikan Islam dan sumber belajar. Kedua, epistemologi sebagai metode atau cara untuk mengelola, yakni berupa proses pengelolaan dan cara untuk

50 Muhammad Ichsan Thaib, “KEPEMIMPINAN DALAM PENDIDIKAN ISLAM," Intelektualita 4, no. 1 (Desember 2018), https://jurnal.arraniry.ac.id/index.php/intel/article/view/3944. h. 66. 
menyiasati problematika yang terjadi. Ketiga, aksiologi sebagai hasil pengelolaan, yaitu berupa pencapaian tujuan pendidikan Islam. ${ }^{51}$ Selanjutnya, rumusan definitif tersebut menjadi titik tekan dalam meneladani manajemen pendidikan Nabi Muhammad untuk melaksanakan ajaran Islam.

Keteladanan yang dapat diambil dari manajemen pendidikan Nabi Muhammad pada generasi milenial adalah adanya kesiapan dalam menghadapi zaman yang terus berubah. Sebab Rasulullah Shalallahu 'alaihi wassalam terbkti berhasil dalam mendidik generasi awal secara khusus dan mengatasi permasalahan secara umum. Raihan tersebut terjadi sebab ketepatan beliau dalam memotret permasalaha problematika umat dan menawarkan solusi strategis. Bahkan adanya kemauan yang kuat dengan didukung oleh akhlak mulia juga menjadi faktor penting dalam mewujudkan langkah solutif tersebut. ${ }^{52}$

Pengelolaan dalam menyelenggarakan pendidikan menjadi hal penting karena menyangkut peran kolektif umat Islam dalam menumbuhkan sikap terbuka. Pentingnya manajemen pada lembaga juga memiliki fungsi sebagai pendukung terhadap proses perencanaan, pengorganisasian, pengkoordinasian, komunikasi, supervisi kepegawaian, pembiayaan dan penilaian. Hal tersebut menjadi rentetan manajemen pendidikan yang bertujuan untuk meningkatkan mutu pendidikan atau pembelajaran di sebuah lembaga. ${ }^{53}$

Manajemen pendidikan yang dilakukan oleh Nabi Muhammad juga memuat adanya kepemimpinan yang kuat untuk menghadapi tantangan zaman dan menyelesaikannya secara proporsional. Idealitas visi dan misi Nabi Muhammad menjadi faktor penting dalam

\footnotetext{
${ }^{51}$ M. Yusuf, “EKSISTENSI DAN PARADIGMA KEILMUAN MANAJEMEN PENDIDIKAN ISLAM," Intizam: Jurnal Manajemen Pendidikan Islam 2, no. 1 (Oktober 2018), h. 48-63. ${ }^{52}$ Abuddin Nata, "PENDIDIKAN ISLAM DI ERA MILENIAL," Conciencia 18, no. 1 (1 Juli 2018), h. 10-28. https://doi.org/10.19109/conciencia.v18i1.2436.

${ }^{53}$ Afiful Ikhwan, "SISTEM KEPEMIMPINAN ISLAMI: INSTRUMEN INTI PENGAMBIL KEPUTUSAN PADA LEMBAGA PENDIDIKAN ISLAM," stawa: Jurnal Pendidikan Islam 3, no. 2 (17 Januari 2019), h. 111-154. https://doi.org/10.24269/ijpi.v3i2.1503.
} 
membangun mental umat yang terbuka dan memiliki pemikiran yang jauh ke depan.

Fungsi kepemimpinan yang ada pada diri Nabi terdiri dari beberapa hal. Pertama, sebagai perintis (pathfinding), Muhammad merintis piagam madinah sebagai undang-undang yang mengatur kedamaian hidup dalam berbangsa dan bernegara. Ia berhasil membangun tatanan sosil yang modern dengan mengenalkan nilainilai kesetaraan universal, spirit multikulturalisme dan rule of low. ${ }^{5455}$

Kedua, penyelaras (aligning), Rasul mampu menyelaraskan adanya perbedaan sehingga tidak timbul konflik yang berkepanjangan. Muhammad terus bekerja sama dan saling bersinergi dalam menyebarkan ajaran Islam yang damai. Ia mampu membangun sistem hubungan yang kuat melalui diplomasi dengan suku-suku dan kerajaan di sekitar Madinah. Sebagai pemimpin, Muhammad juga berhasil menguatkan sistem pertahanan Madinah sehingga menjadi daerah yang kuat dan memiliki pengaruh. ${ }^{56}$

Ketiga, pemberdaya (empowering), Muhammad menumbuhkan lingkungan yang baik sehingga masyarakat juga berkenan untuk memberikan yang terbaik. Rasulullah mampu menyinergikan beragam potensi yang ada untuk mencapai sebuah tujuan. Seperti menyatukan kaum Muhajirin dan Anshar dalam membangun masyarakat Madinah. ${ }^{57}$ Selain itu, ketetapan seperti adanya pajak dan zakat juga menjadi bukti Muhammad dalam memberdayakan umat.

Keempat, panutan (modeling), Nabi Muhammad berkenan untuk bertanggung jawab atas ucapan, sikap, perilaku dan segala keputusan yang diambilnya. ${ }^{58}$ Rasulullah terbukti dan pantas untuk menjadi

\footnotetext{
${ }^{54}$ Muhammad Khairul Umam, "IMAM PARA NABI: MENELUSUR JEJAK KEPEMIMPINAN DAN MANAJERIAL NABI MUHAMMAD SAW,” Jurnal al Hikmah 6, no. 1 (10 Maret 2018). h. 59-74

${ }^{55}$ Syafi'i Antonio Muhammad, Muhammad SAW The Super Leader Super Manager (Jakarta: Tazkia Publishing \& ProLM Centre, 2009). h. 20

${ }^{56}$ Muhammad.

${ }^{57}$ Muhammad. h. 21-22

${ }^{58}$ Khairul Umam, "IMAM PARA NABI: MENELUSUR JEJAK KEPEMIMPINAN DAN MANAJERIAL NABI MUHAMMAD SAW.” h. 54-74
} 
panutan manusia dalam menegakkan keadilan dan mewujudkan perdamaian di tengah keragaman masyarakatnya.

Usaha yang dilakukan oleh Nabi Muhammad dalam menumbuhkan sikap toleran juga melalui pendekatan berbasis nilainilai kearifan lokal. Islam dan budaya diyakini sebagai hal yang mengajarkan pada nilai-nilai kebaikan yang bertujuan untuk membuat keteraturan bagi sekelompok manusia. Sehingga pendidik dituntut mampu memahami nilai-nilai historis dan filosofis dari budaya yang berkembang di masyarakat, kemudian dapat diinternalisasikan dengan nilai-nilai keIslaman. Hal tersebutlah yang dilakukan oleh Muhammad, sehingga diterapkanlah keadilan, kejujuran, persamaan, kebebasan, persaudaraan, musyawarah. Semua aspek tersebut dilakukan untuk menuju kemaslahatan hidup yang berkesinambungan, baik kehidupan secara individual maupun secara sosial. ${ }^{59}$

Kehidupan individual dan sosial tidak bisa dipisahkan begitu saja, sebab keduanya adalah satu kesatuan yang saling membutuhkan. Kebutuhan individu dapat terpenuhi oleh bantuan komunitas sosial. Begitu juga sebaliknya, kebutuhan sosial dapat terpenuhi oleh dukungan kekuatan-kekutan individu yang bersatu. Sehingga kekuatan tergantung oleh manusia secara perorangan dan kelompok, terlebih dalam masyarakat.

Toleransi sosial masyarakat Islam terhadap masyarakat lain adalah bukti keberhasilan pendidikan. Hal tersebut patut menjadi cermin kehidupan dan contoh dalam menjalankan dakwah sebagai langkah menebar spirit toleransi. Nabi Muhammad terbukti mampu menyelesaikan masalah kehidupan sosial budaya, sebab Rasulullah memberikan kesempatan dialogis secara terbuka dan interaksionis fenomenologis. Nabi Muhammad menyelesaikan permasalahan melalui dialog interaktif dengan para sahabat dan umat yang berbeda. Dialog dilakukan dengan pengakuan bahwa tiap agama memiliki

\footnotetext{
${ }^{59}$ Abdul Wahid, “DAKWAH DALAM PENDEKATAN NILAI-NILAI KEARIFAN LOKAL (TINJAUAN DALAM PERSPEKTIF INTERNALISASI ISLAM DAN BUDAYA)," Jurnal Dakwah Tabligh 19, no. 1 (8 September 2018), h. 1-19. https://doi.org/10.24252/jdt.v19i1.5908.
} 
keyakinan yang teguh dan mutlak, namun keyakinan yang ada berbeda. ${ }^{60}$

Pendidikan yang dilakukan di basis multikultural juga tetap harus dilakukan dengan memperhatikan nilai-nilai budaya yang ada pada masyarakat yang majemuk atau kondisi warga yang beraneka ragam dengan berbagai kekhasannya. Materi dan objek dakwah menjadi penting untuk dipahami dalam membangun peradaban masyarakat yang toleran.

Sikap toleransi perlu ditumbuhkan karena pluralisme suku, agama, ras adalah kehendak dan sunnah Allah. Perbedaan merupakan rahmat dan kebaikan yang dapat dijadikan pendorong untuk kemajuan umat manusia. Hal itu dapat dicapai dengan mengelola secara baik hal-hal yang perlu dimanajemen sesuai dengan kesepakatan bersama. Sebab setiap agama memiliki ajaran tersendiri. Namun jalan kekerasan terhadap penganut agama lain tidak dibenarkan dalam konteks hidup bersama. ${ }^{61}$ Rasulullah juga mengajarkan untuk mendidik secara ramah. Bahkan pendidikan yang beliau lakukan kepada para penguasa juga dilakukan dengan lembut dan ajakan pada kebaikan. Terlebih ia mengajak para raja untuk memeluk agama Islam seperti melalui korespondensi yang menggunakan kalimat santun dalam melaksanakan tugas sebagai pendidik umat. ${ }^{62}$

Langkah-langkah solutif perlu dilakukan dalam meneladani sikap Nabi Muhammad dalam mendidik umat. Solusi yang dapat dihadirkan adalah dengan menyelenggarakan pendidikan inklusif sebagai sarana mengejewantahkan nilai-nilai kemanusiaan.

\footnotetext{
${ }^{60}$ M. Fuad Anwar, "FENOMENOLOGI DAKWAH (DAKWAH DALAM PARADIGMA SOSIAL BUDAYA)," Empower: Jurnal Pengembangan Masyarakat Islam 3, no. 2 (16 November 2018), https://doi.org/10.24235/empower.v3i2.3512. h. 110.

${ }^{61}$ A. Rahman Ritonga, "MENDAMAIKAN KEBERAGAMAN MELALUI PENGUATAN TOLERANSI DAN KERUKUNAN ANTAR KOMUNITAS MULTI AGAMA,” ALHURRIYAH: Jurnal Hukum Islam (ALHURRIYAH JOURNAL OF ISLAMIC LAW) 13, no. 1 (11 Juli 2018), https://doi.org/10.30983/alhurriyah.v13i1.578.

${ }^{62}$ Abdul Ghoni, "MENGGAGAS DAKWAH KORESPONDENSI NABI MUHAMMAD SAW," Jurnal Ilmu Dakwah 37, no. 1 (23 Juli 2018), h. 80-153. https://doi.org/10.21580/jid.v37.1.2623.
} 
Manajemen pendidikan perlu diselenggarakan untuk semua orang, sehingga dapat menyentuh seluruh lapisan elemen masyarakat.

Kunci dari keberhasilan Nabi adalah terletak pada pola komunikasi yang baik. Rasulullah menyebarkan pesan-pesan ketuhanan kepada masyarakat dengan menggunakan komunikasi yang baik. Muhammad mendidik dengan memperhatikan budaya masyarakat. Pada aras yang sama, kearifan lokal dapat bersinergi dengan ajaran yang dibawa oleh Rasulullah melalui sarana budaya dan tradisi masyarakat. Sehingga komunikasi dapat berjalan baik dan pendidikan yang diberikan dapat menarik minat audience sebagai penyebaran Islam yang rahmatan lil 'alamin. ${ }^{63}$

Usaha untuk menumbuhkan sikap toleransi kepada masyarakat dilakukan Nabi Muhammad dengan memperhatikan kondisi warga. Hal itu dilakukan dengan menganalisis keinginan, kebutuhan tiap masyarakat, sehingga Nabi sebagai pemimpin dan pendidik mampu merumuskan dan menetapkan kebijakan untuk masyarakat. Keterbukaan Nabi Muhammad dalam membaca realitas multikultural menjadi faktor penting dalam manajemen pendidikan yang dilakukannya. Tujuan dari penyelenggaraan pendidikan struktural dan kultural adalah tumbuhnya sikap toleran yang saling menghormati, menghargai, dan saling menolong dalam nuansa kemanusiaan.

\section{F. Konteks Pancasila dan Piagam Madinah}

Indonesia sejak sebelum kemerdekaan merupakan sebuah bangsa (Nusantara) telah eksis sebagai wilayah maritim yang memiliki kekayaan etnik, kultur, dan agama. Hal tesebut telah disadari keberadaannya oleh para pejuang kemerdekaan, sehingga mereka merumuskan pancasila sebagai dasar negara. Pancasila menjadi pedomanan dalam kehidupan masyarakat yang plural dan multikultural.

\footnotetext{
63 Mohamad Abdul Hanif, "MENGKOMBINASIKAN DAKWAH DENGAN BUDAYA SEBAGAI LANGKAH MENINGKATKAN ANTUSIASME MASYARAKAT (ANALISIS USES DAN GRATIFICATIONS THEORY) " AL Iman: Jurnal Keislaman Dan Kemasyarakatan 2, no. 1 (9 September 2018). h. 65-347
} 
Jauh sebelum kelahiran Pancasila, pada abad ketujuh, Islam telah merancang konstitusi tertulis yang mengatur tentang kehidupan antar suku-suku di Arab di samping juga memuat sistem berbangsa dan bernegara, yang kemudian dikenal dengan sebutan "Piagam Madinah". ${ }^{64}$ Posisi Piagam Madinah sampai saat ini masih dijadikan sebagai rujukan baik oleh kalangan negarawan, akademisi, ahli tatanegara, dan lainnya dalam merspon berbagai konflik kebangsaan dan kenegaraan. ${ }^{65}$ Berikut sekilas uraian tentang Pancasila dan Piagam Madinah:

Pertama, dalam konteks Pancisila, Indonesia sejak dekade 70-an telah mengalami prubahan besar-besaran di segala bidang. Hal itu tecermin dari penyelenggaraan mega proyek Repelita (Rencana Pembangunan Lima Tahun) pada masa Orde Baru. Pembangunan tersebut ditujukan agar Indonesia dapat bersaing dengan negaranegara maju di Eropa dan negara-negara berkembang di Asia. Namun demikian, mega proyek tersebut di satu sisi mengalami kendala serius, yakni ketidaksanggupan pihak-pihak yang bertanggungjawab di dalam menjalankan amanhnya, di mana banyak dari mereka yang tersandung kasus korupsi, kolusi dan nepotisme yang kemudian kita kenal dengan istilah KKN.

Sementara itu, di sisi lain, pembangungan tersebut membawa dampak pada meningkatnya interaksi sosial, tidak hanya di level elit politik, akan tetapi juga sampai di pelosok-pelosok desa. Adanya infrastruktur yang dibangun besar-besaran (termasuk pembuatan jalan untuk memudahkan jalur transportasi) oleh negara memungkinkan terjadinya pola relasi antar etnis, bahkan antar suku yang kemudian disebut dengan istilah "tapestri", Pola tapestri menggambarkan bahwa tidak sedikit dari masyarakat pedalaman, baik secara terpaksa maupun sukarela, melakukan interaksi dengan dunia luar yang berbeda dengan dunia mereka. ${ }^{66,67}$

\footnotetext{
${ }^{64}$ Komkelo, Kholish, dan Aulia Ali, Fiqh HAM: Ortodoksi dan Liberalisme Hak Asasi Manusia dalam Islam.

${ }^{65}$ Baca: Luth, Kholish, dan Zainullah, Bernegara dalam Islam.

${ }^{66}$ Lihat, Baidhawy, Fikih Kebhinekaan: Pandangan Islam Indonesia tentang Umat, Kewargaan, dan Kepemimpinan Non-Muslim.
} 
Di samping KKN dan tapestri, rakyat Indonesia juga mengalami diskriminasi dan ketidakadilan. Hal tersebut mengakibatkan terjadinya kesenjangan antar komunitas-masyarakat, antar-kultur dan sub-kultur. Kelas sosial semakin kentara, antara yang bawah dan atas, superior-inferior, rakyat-pejabat, rakyat-konglomerat yang lambat laun mengarah pada penindasan yang berjalan secara sistemik, terstrukur dan banyak menelan korban jiwa. Saat itu, Rezim Soeharto menempatkan minoritas Tionghoa sebagai objek asimilasi yang kemudian menjadikan penduduk Tionghoa sebagai sasaran diskriminasi, pemerasan, dan kekerasan baik secara fisik maupun verbal.

Di samping itu, pemerintah juga memberlakukan kebijakan segregasi dalam hal keagamaan dan kepercayaan. Dampak dari kebijakan tersebut berakibat pada aliran-aliran kepercayaan dan penghayat kebatinan yang dianjurkan untuk melebur dan memilih agama yang telah ditentukan oleh pemerintah serta mendaftarkan diri kepada Kementrian Pendidikan dan Kebudayaan. Pada tahun 1970, aliran penghayat kepercayaan yang menurut data mencapai 200 kelompok, kemudian dihimpun dan dibina oleh pemerintah melalui Direktorat Bina Hayat, Kemendikbud. Pada Tahun 1997 pemerintah juga memasukkan aliran kebatinan dan kepercayaan terhadap Tuhan YME ke dalam GBHN 1998 dan pada perkembangannya, UU Nomor 24 tahun 2013 dinilai sebagai pembatasan hak oleh para penganut aliran kepercayaan. ${ }^{68}$

Selanjutnya, pemerintah Orde Baru juga melakukan segregasi antara agama "resmi" (Islam, Kristen, Katholik, Buddha, Hindu) dan "tidak resmi". Penganut Kong Hucu pada saat itu dianggap sebagai 'saudara sepersusuan' Komunisme dan tidak dianggap sebagai agama resmi oleh pemerintah. Pun demikian dengan agama-agama dan aliran kepercayaan asli Nusantara yang tidak dianggap sebagai agama.

67 Lihat, Hedy Shri Ahimsa-Putra, "Indonesia: Cultural Pluralism without Multiculturalism?," dalam Multicultural Education: Cross-Cultural Understanding for Democracy and Justice (Yogyakarta: CRSD UIN Sunan Kalijaga, 2005).

${ }^{68}$ Baidhawy, Fikih Kebhinekaan: Pandangan Islam Indonesia tentang Umat, Kewargaan, dan Kepemimpinan Non-Muslim. 
Wal hasil, mereka yang secara turun temurun memegang keyakinan dan kepercayaan asli lelurnya dipaksa untuk memilih dan mencantumkan agama pilihan negara sebagai identitasnya.

Krisis pemahaman Pancasila sebagaimana sila "Ketuhanan Yang Maha Esa" di atas, juga berakibat pada penghakiman bahwa Pancasila dan tiga pilar lainnya yaitu UUD 1945, NKRI dan Bhinneka Tunggal Ika adalah idelogi thaghut. bahkan, Jamaah Islamiyah (JI) dalam tekadnya untuk mendirikian "Negara Islam" telah menghalalkan bughat (pemberontakan) dan fa'i (melakukan perampokan terhadap pemerintah) untuk dijadikan sebagai bekal dan biaya jihad mereka. ${ }^{69}$

Setelah sila pertama, sila kedua menegaskan tentang relasi kemanusiaan yang berkeadaban, di mana sila ini merupakan pengejawantahan relasi antar umat manusia yang juga berhubungan dengan sila pertama. Dalam penerapannya, sila kedua "Kemanusiaan yang adil dan beradab" harus ditopang dengan sikap egalitarianisme (persamaan dan kesetaraan). Selain itu, sila ini juga harus didorong dengan sikap anti entnosentrisme, yakni menolak atas dominasi ras dan segala bentuk diskriminasi.

Pun demikian dengan sila ketiga, "Persatuan Indonesia". Dengan sila tersebut, rakyat Indonesia diharapkan dapat menjaga nyala persatuan dan kesatuan bangsanya. Sila ini juga erat kaitannya dengan semboyan "Bhinneka Tunggal Ika", bangsa yang satu di tengah keanekaragaman budaya, bahasa, agama, dan lainnya. Oleh sebab itu, keberadaan sila ini sangat penting untuk mengukuhkan solidaritas nasional sebagai bentuk kecintaan pada negara (hubbul wathan).

Selanjutnya adalah silah keempat dan kelima. Sila keempat memperkuat posisi kemanusiaan bahwa manusia telah dilimpahkan tanggungjawab untuk berdaulat oleh Tuhannya. Oleh karenanya, sikap manusia sebagai pemimpin (ra'iyah) di muka bumi mutlak dibutuhkan. Kepemimpinan membutuhkan kedewasaan dan kematangan berpikir sehingga tugas manusia dalam melayani sesamanya dapat terlaksana dengan baik dan sesuai aturan. Sementara

${ }^{69}$ Baca: Solahudin, NII sampai JI: Salafi Jihadisme di Indonesia (Jakarta: Komunitas Bambu, 2011). 
sila kelima merupakan simpul di dalam terlaksananya keadilan secara merata, bahwa keadilan bukanlah milik sebagian golongan, tetapi bagi seluruh rakyat Indonesia, tanpa terekcuali. Dalam keadilan ekonomi misalnya, dibutuhkan semacam redistribusi kekayaan dan pendapatan. Begitu juga dalam kerja-kerja membangun dan mencerdaskan bangsa yang membutuhkan distribusi tenaga dan pemikiran dari seluruh elemen masyarakat Indonesia.

Adapun yang kedua, istilah Piagam Madinah pertama kali disebutkan oleh Ibnu Hisyam. Hisyam menuturkan tentang catatan laporan Ibn Ishaq ${ }^{70}$ yang menyebutkan tentang kilas sejarah terbentuknya Piagam Madinah pada zaman Nabi Muhammad SAW. Selanjutnya, setelah Ibnu Hisyam, terdapat sumber otoritatif lain yang juga mencantumkan istilah Piagam Madinah, yaitu Gharib al-Hadits karya Abu Ubaid dan Tabaqat karya Ibnu Sa'ad dan beberapa kitab lainnya. Mayoritas sejarawan Islam dan para ulama saat itu memberikan kesaksian bahwa secara otentik, perjanjian Piagam Madinah berlangsung di rumah Anas bin Malik, salah seorang sahabat Nabi. Piagam madinah juga disebut sebagai shahifah atau buku yang disusun secara sungguh-sungguh dan dicatat sesuai urutan pasal perpasal.

Kesahihan Piagam Madinah yang turut ditandatangani oleh bebagai suku (komunitas) di Arab saat itu menurut pakar sejarawan muslim modern dianggap sebagai perjanjian hukum pertama yang yang tertulis dalam sejarah umat manusia. Muatan Piagam Madinah salah satunya adalah berisi tentang pasal-pasal perdamaian antar suku bahwa mereka adalah umat yang satu. Di samping itu, juga berisi tentang hak dan kewajiban penguasa/pemerintah berikut peran-peran strategis negara. Walaupun keberadaan Piagam Madinah (sebagai satu kesatuan dokumen) masih diperdebatkan oleh sebagian sejarawan, namun bukti otentik menunjukkan bahwa Piagam Madinah telah ditulis setelah masa hijrahnya Nabi, yakni ketika Nabi Muhammad

${ }^{70}$ Lihat, Baidhawy, Fikih Kebhinekaan: Pandangan Islam Indonesia tentang Umat, Kewargaan, dan Kepemimpinan Non-Muslim; Baca juga: Muhammad Ibn Ishaq, Al-Sirah al-Nabawiyah (Beirut: Dar al-Kitab al-Islamiyah, 2007). 
menjadi hakim dan arbiter di Madinah yang kemdian dikenal dengan sebutan "Periode Madinah". Pada saat itu Rasulullah SAW diundang oleh kaum Anshar untuk bertindak sebagi hakim dalam mengatasi konflik antar suku Arab yang ada di Madinah. ${ }^{71}$

Sebagaimana diketahui bahwa Madinatul Munawwarah adalah sebuah negara kota yang dibentengi oleh konstitusi kokoh bernama Piagam Madinah yang secara langsung digagas oleh Nabi Muhammad SAW berdasarkan konsensus semua kepala suku pada tahun $622 \mathrm{H}$. Piagam Madinah yang dideklarasikan oleh Nabi Muhammad tersebut di antaranya memuat tentang asas kesatuan "ummah". Hal tersebut tercantum di beberapa pasal sebagaimana uraian berikut:

"Pasal 1: Atas nama Allah Yang Maha Pemurah Lagi Maha Penyayang. Ini adalah dokumen (piagam) dari Nabi Muhammad SAW antara orang-orang beriman dan orang-orang yang memeluk Islam dari Quraisy (Muhajirin) dan penduduk Yatsrib (Anshar dan Yahudi/non-Muslim) dan siapa pun yang mengikuti mereka dan termasuk dalam kelompok mereka dan berjuang bersama mereka (aliansi mereka)."

"Pasal 2: Bahwa mereka (Penduduk Madinah) adalah satu ummah; berbeda dari yang lain."

"Pasal 25: Kaum Yahudi dari Bani 'Auf adalah satu umat dengan Mukminin. Bagi kaum Yahudi agama mereka, dan bagi kaum muslimin agama mereka. Juga (kebebeasan ini berlaku) bagi sekutu-sekutu dan diri mereka sendiri, kecuali bagi yang zalim dan jahat. Hal yang demikian akan merusak diri dan keluarga."

Di samping ketiga eksemplar pasal di atas, pasal lainnya juga memuat tentang hukuman atas Bani Qaynuqa, Bani Nadir, dan Bani Quraidzah karena mereka melakukan pengkhianatan. Beberapa peneliti Piagama Madinah, seperti Che Noh juga memberikan sumbangsinya dalam penelusuran detail per pasal, baik yang berhubungan dengan kedudukan Nabi Muhammad sebagai pemimpin

${ }^{71}$ Lihat, Baidhawy, Fikih Kebhinekaan: Pandangan Islam Indonesia tentang Umat, Kewargaan, dan Kepemimpinan Non-Muslim; Baca juga: Jonathan Porter Berkey, Jonathan The Formation of Islam: Religion and Society in the Near East, 600-1800, vol. 2, Themes in Islamic History (New York: Cambridge University Press, 2003). 
di Madinah, pasal tentang pedoman negara Madinah (A-Qur'an dan Al-Sunnah), hak dan tanggungjawab semua warga Madinah, tanggungawab semua muslim dan non muslim, dan pasal-pasal lainnya. ${ }^{72}$ Pada titik inilah Islam sebagai ajaran yang universal harus mampu diaktualisasikan secara particular dalam konteks keindonesiaan, sebab jika Islam tidak mampu berdialog dengan konteks ruang dan waktu, maka Islam akan dipertanyakan universalitasnya yang sholih likully zaman wal makan, termasuk dalam konteks menjawab multikulturalisme dan kebhinekaan di Indonesiaan. ${ }^{73}$

\section{G. Penutup}

Posisi Nabi Muhammad kerapkali absen dilihat sebagai peletak dasar multikulturalisme. Posisi Nabi Muhammad sebagai kepala negara yang mampu menginisiasi lahirnya piagam Madinah justeru harus dilihat sebagai cikal bakal teoritis pendidikan multikulturalisme. Dalam rangka mewujudkan pendidikan multikulturalisme tersebut, Nabi Muhammad menjadikan teologi rahmatan lil alamin sebagai bahan bakar kognitif, afektif dan psikomotorik. Masyarakat Madinah yang plural diedukasi oleh Nabi Muhammad melalui nilai-nilai ajaran Islam yang universal seperti keadilan, egalitarianisme, kejujuran, cinta kasih, dan perdamaian. Keteladanan Nabi Muhammad dengan akhlaknya yang universal menjadi modal penting terwujudnya sikap toleransi dalam menyikapi multikulturalisme masyarakat Madinah.

${ }^{72}$ Lihat, Baidhawy, Fikih Kebhinekaan: Pandangan Islam Indonesia tentang Umat, Kewargaan, dan Kepemimpinan Non-Muslim; Baca juga: Ibrahim Che Noh, "PrinsipPrinsip Perpaduan Kaum di Malaysia: Satu Kajian Menerusi Piagam Madinah dan alQur'an dan al-Sunnah ," (Selangor, Department of Islamic Da'wa and Leadership, University Kebangsaan Malaysia, 2001) Lihat juga, Mujaid Komkelo, Moh Anas Kholish, dan Fiqh Vredian Aulia Ali, Fiqh HAM: Ortodoksi dan Liberalisme Hak Asasi Manusia dalam Islam (Malang: Setara Press, 2015)..

${ }^{73}$ Lihat, Moh Anas Kholish dan Nor Salam, Epistemologi Hukum Islam Transformatif; Sebuah Tawaran Metodologis Dalam Pembacaan Kontemporer (Malang: UIN Maliki Press, 2015); Baca juga, Moh Anas Kholish dan Nor Salam, Hukum Islam Progresif (Malang: Setara Press, 2020). 
Indonesia sebagai negara yang terdiri dari berbagai varian ras, suku, agama dan budaya menjadi relevan untuk me-landing-kan nilainilai multikulturalisme yang pernah dicontohkan Nabi Muhammad di Madinah. Pada waktu yang bersamaan Pancasila yang dijadikan sebagai falsafah hidup bernegara oleh masyarakat Indonesia selaras dengan ajaran-ajaran tentang toleransi di tengah kehidupan multikulturalisme masyarakat Madinah. Keragaman agama, suku dan budaya mampu disulam dan dirajut secara harmoni melalui nilai-nilai Islam yang universal sebagaimana yang tertuang dalam Pancasila.

\section{Daftar Pustaka}

Abdul Hanif, Mohamad. “MENGKOMBINASIKAN DAKWAH DENGAN BUDAYA SEBAGAI LANGKAH MENINGKATKAN ANTUSIASME MASYARAKAT (ANALISIS USES DAN GRATIFICATIONS THEORY).” AL Iman: Jurnal Keislaman Dan Kemasyarakatan 2, no. 1 (9 September 2018).

Abdullah. "KOMPLEMENTARITAS DAKWAH KULTURAL DAN STRUKTURAL.” Jurnal Pemberdayaan Masyarakat 4, no. 4 (6 November 2018).

http://jurnal.uinsu.ac.id/index.php/PEMAS/article/view/2625.

Ahimsa-Putra, Hedy Shri. "Indonesia: Cultural Pluralism without Multiculturalism?” Dalam Multicultural Education: Cross-Cultural Understanding for Democracy and Justice. Yogyakarta: CRSD UIN Sunan Kalijaga, 2005.

Ahnu Idris, Muhammad. "DAKWAH PADA MASYARAKAT DAERAH TERPENCIL: METODE DA'WAH BI AL-HAL SEBAGAI UPAYA MENINGKATKAN TARAF KEHIDUPAN MAD'U.” 'Ulumuna: Jurnal Ilmu Keilsman 3, no. 1 (2018).

Al-Bukhari, Al-Imamal-Hafidz Abi 'Abdillah Ibn Isma'il. Shahīhu-lBukhāri, Dār Ibn Hazm. Libanon: Beirut, 2003.

Anas Kholish, Moh, dan Nor Salam. Hukum Islam Progresif. Malang: Setara Press, 2020. 
Aravik, Havis. "HAK MINORITAS DALAM KONTEKS ISLAM.” Mizan: Journal of Islamic Law 5, no. 1 (14 Juni 2018). https://doi.org/10.32507/mizan.v5i1. h. 195.

Azis, Abdul, dan Nor Muslim. "TANTANGAN DAKWAH PADA MASYARAKAT MULTIKULTURAL DI KALIMANTAN TENGAH.” Wardah 19, no. 2 (Desember 2018).

Baidhawi, Zakiyuddin. Pendidikan Agama Berwawasan Multikultural. Jakarta: Erlangga, 2005.

Baidhawy, Zakiyuddin. Fikih Kebhinekaan: Pandangan Islam Indonesia tentang Umat, Kewargaan, dan Kepemimpinan Non-Muslim. Bandung: PT Mizan Pustaka, 2015.

Basri, Hasan. "MANAJEMEN DAKWAH NABI MUHAMMAD SAW DI MADINAH.” Al-MUNZIR 8, no. 2 (15 Maret 2018). https://doi.org/10.31332/am.v8i2. 743.

Che Noh, Ibrahim. “Prinsip-Prinsip Perpaduan Kaum di Malaysia: Satu Kajian Menerusi Piagam Madinah dan al-Qur'an dan al-Sunnah ,." Department of Islamic Da'wa and Leadership, University Kebangsaan Malaysia, 2001.

Dwi, Retna. “DAKWAH ISLAM: ANTARA DAMAI DAN PERANG.” $A l$ Tsiqoh : Jurnal Ekonomi Dan Dakwah Islam 4, no. 1, April (5 April 2019): 1-17.

Fuad Anwar, M. "FENOMENOLOGI DAKWAH (DAKWAH DALAM PARADIGMA SOSIAL BUDAYA).” Empower: Jurnal Pengembangan Masyarakat Islam 3, no. 2 (16 November 2018). https://doi.org/10.24235/empower.v3i2.3512.

Ghoni, Abdul. "MENGGAGAS DAKWAH KORESPONDENSI NABI MUHAMMAD SAW." Jurnal Ilmu Dakwah 37, no. 1 (23 Juli 2018). https://doi.org/10.21580/jid.v37.1.2623.

Hmz, Nandang. "DARI PIAGAM MADINAH KE PLURALITAS KEPEMIMPINAN NABI MUHAMMAD SAW." Dalam Prosiding SNaPP: Sosial, Ekonomi dan Humaniora, Vol. 4. 1, 2018. 
Ibn Ishaq, Muhammad. Al-Sirah al-Nabawiyah. Beirut: Dar al-Kitab alIslamiyah, 2007.

Ibnul Jauzi. Al-Wafa: Kesempurnaan Pribadi Nabi Muhammad. Jakarta Timur: Pustaka al-Kautsar, 2018.

Ichsan Thaib, Muhammad. "KEPEMIMPINAN DALAM PENDIDIKAN ISLAM." Intelektualita 4, no. 1 (Desember 2018). https://jurnal.arraniry.ac.id/index.php/intel/article/view/3944. h. 66.

Ikhwan, Afiful. "SISTEM KEPEMIMPINAN ISLAMI: INSTRUMEN INTI PENGAMBIL KEPUTUSAN PADA LEMBAGA PENDIDIKAN ISLAM.” stawa: Jurnal Pendidikan Islam 3, no. 2 (17 Januari 2019). https://doi.org/10.24269/ijpi.v3i2.1503.

Iskandar dkk., Iskandar. "DAKWAH INKLUSIF DI KOTA PAREPARE.” KOMUNIDA : Media Komunikasi dan Dakwah 8, no. 2 (Desember 2018). https://doi.org/10.35905/komunida.v8i2.632.

Khairi Mahyuddin, Muhammad. "Tasawuf dan Peembangunan Rohani di Kalangan Masyarakat.” Jurnal Ushuluddin Adab Dan Dakwah 1, no. 2 (2018).

Khairul Umam, Muhammad. "IMAM PARA NABI: MENELUSUR JEJAK KEPEMIMPINAN DAN MANAJERIAL NABI MUHAMMAD SAW.” Jurnal al Hikmah 6, no. 1 (10 Maret 2018).

Kholish, Moh Anas. Menyemai Pendidikan Fikih Beyond The World: Menumbuhkan Living Toleransi di Tengah Kebinekaan Mazhab Fikih di Indonesia. Malang: Intrans dan Intelegensia, 2021.

Kholish, Moh Anas, dan Khalid Rahman. Menjadi Muslim Nusantara Rahmatan Lil 'Alamiin. Yogyakarta: Laila Pustaka, 2015.

Kholish, Moh. Anas, dan Siti Rohmah. "Menjembatani Antara Misi Proselitisasi Islam-Kristen dan Keharusan Merawat Kerukunan:Konstruksi Teologis Forum Kerukunan Umat Beragama (FKUB) Kota Malang." Islamic Insights Journal 2, no. 1 $(10$ September 2020): $55-66$. https://doi.org/10.21776/ub.iij.2020.002.01.4. 
Kholish, Moh Anas, dan Nor Salam. Epistemologi Hukum Islam Transformatif; Sebuah Tawaran Metodologis Dalam Pembacaan Kontemporer. Malang: UIN Maliki Press, 2015.

Kholish, Moh Anas, dan Ismail Suardi Wekke. “Fiqh Education Based on Internal Tolerance of Religious Society of Religious Ideology Variance." International Journal of Pure and Applied Mathematics 119 , no. 18 (2018).

Komkelo, Mujaid, Moh Anas Kholish, dan Fiqh Vredian Aulia Ali. Fiqh HAM: Ortodoksi dan Liberalisme Hak Asasi Manusia dalam Islam. Malang: Setara Press, 2015.

Kosim, Mohammad. "INSTITUSI POLITIK DI ZAMAN NABI MUHAMMAD SAW." Islamuna: Jurnal Studi Islam 2, no. 1 (5 Juni 2015): 1-15. https://doi.org/10.19105/islamuna.v2i1.651.

Luth, Thohir, Moh Anas Kholish, dan Moh. Zainullah. Bernegara dalam Islam. Malang: UB Press, 2018.

M. Lapidus, Ira. Sejarah Sosial Ummat Islam. Jakarta: Raja Grafindo Persada, 2000.

Misrawi, Zuhairi. Madinah: Kota Suci, Piagam Madinah, dan Teladan Muhammad SAW. Jakarta: Kompas, 2009.

Muhammad, Syafi'i Antonio. Muhammad SAW The Super Leader Super Manager. Jakarta: Tazkia Publishing \& ProLM Centre, 2009.

Nasution, Harun. Teologi Islam. Jakarta: UI-Press, 1986.

Nata, Abuddin. Ilmu Pendidikan Islam. Jakarta: Kencana Pranada Media Group, 2010.

- - . "PENDIDIKAN ISLAM DI ERA MILENIAL.” Conciencia 18, no. 1 (1 Juli 2018). https://doi.org/10.19109/conciencia.v18i1.2436.h. $10-28$.

Nurdiyati, Wahyu, Erna Mufidah M, Nashiiruddin Addaai, Agus Ishom, dan Choirul Mahfud. "SEJARAH SOSIAL PENDIDIKAN ISLAM 
PADA ERA KENABIAN.” HIKMAH: Jurnal Pendidikan Islam 8, no. 1 (11 Juni 2019): 3.

Porter Berkey, Jonathan. The Formation of Islam: Religion and Society in the Near East, 600-1800. Vol. 2. Themes in Islamic History. New York: Cambridge University Press, 2003.

Ritonga, A. Rahman. "MENDAMAIKAN KEBERAGAMAN MELALUI PENGUATAN TOLERANSI DAN KERUKUNAN ANTAR KOMUNITAS MULTI AGAMA.” ALHURRIYAH: Jurnal Hukum Islam (ALHURRIYAH JOURNAL OF ISLAMIC LAW) 13, no. 1 (11 Juli 2018). https://doi.org/10.30983/alhurriyah.v13i1.578.

Rohmah, Siti, dan M. Anas Budiarjo. Islam dalam Narasi Sejarah dan Peradaban. Malang: UB Press, 2018.

Rohmah, Siti, M. Syukri Ismail, Moh. Anas Kholish, dan Mona Novita. "Recontextualization of Islamic Peace Education: A Study of the Theory of Mohammed Abu-Nimer in the Indonesian Context." Fieldwork in Religion 13, no. 2 (20 Desember 2018): 183-202. https://doi.org/10.1558/firn.37545.

Sambas, Sukriadi, Indira Sabet, dan Ratna Dewi. "Dakwah Islam Multikultural Pada Komunitas Sunda, Arab Alawi Dan Arab Irsyadi." Anida (Aktualisasi Nuansa Ilmu Dakwah) 19, no. 1 (25 Juni 2019). https://doi.org/10.15575/anida.v19i1.5067.

Sarwat, Ahmad. Madinah Era Kenabian: Kajian Kritis Sirah Nabawiyah Madinah dalam Agama, Sosial dan Politik. Jakarta: Rumah Fiqih Publishing, 2018.

Setiawan, Agung Ibrahim, dan M. Al-Qautsar Pratama. "Karakteristik Pendidikan Islam Periode Nabi Muhammad Di Makkah dan Madinah." NALAR: Jurnal Peradaban dan Pemikiran Islam 2, no. 2 (31 Desember 2018): $130-37$. https://doi.org/10.23971/njppi.v2i2.958. 
Sholikhin, Amrotun. "Piagam Madinah Konsensus Masyarakat Pluralis Madinah dan Makkah (Suatu Tinjauan Teori Konflik).” Jurnal Komunika 9, no. 1 (Juni 2015).

Sjadzali, Munawir. Islam dan Tata Negara. Jakarta: UI Press, 1990.

Solahudin. NII sampai JI: Salafi Jihadisme di Indonesia. Jakarta: Komunitas Bambu, 2011.

Ulya, Inayatul. "Radikalisme Atas Nama Agama: Tafsir Historis Kepemimpinan Nabi Muhammad di Madinah” 10, no. 1 (Februari 2016).

Wahid, Abdul. "DAKWAH DALAM PENDEKATAN NILAI-NILAI KEARIFAN LOKAL (TINJAUAN DALAM PERSPEKTIF INTERNALISASI ISLAM DAN BUDAYA).” Jurnal Dakwah Tabligh 19, no. 11 (8 September https://doi.org/10.24252/jdt.v19i1.5908.

Yasir, Muhammad. “Makna Toleransi Dalam Al-Qur'an.” Jurnal Ushuluddin 22, no. 2 (1 Desember 2014): 170-80. https://doi.org/10.24014/jush.v22i2.734.

Yunus, Mamud. Sejarah Pendidikan Islam. Purwokerto: Hidakarya Agung, 1992.

Yusuf, M. "Eksistensi dan Paradigma Keilmuan Manajemen Pendidikan Islam.” Intizam: Jurnal Manajemen Pendidikan Islam 2, no. 1 (Oktober 2018). https://doi.org/h. 48-63.

Zahra, Abu (ed.). Politik Demi Tuhan: Nasionalisme Religius di Indonesia,. Bandung: Pustaka Hidayah, 1999.

Zuhairini, et.all. Sejarah Pendidikan Islam. Jakarta: Dirjen Binbaga Islam Depag RI, 1986. 